\title{
THE ORGAN CONCERTOS OF HENRY BURGESS (1718-1786)
}

\author{
MICHAEL TALBOT \\ University of Liverpool
}

Izvleček: Henry Burgess mlajši je leta 1743 objavil prvo znano zbirko orgelskih koncertov izpod peresa kakega angleškega skladatelja. V njih je viden močan vpliv Georga Friedricha Händla, ki je z orgelskimi koncerti, objavljenimi leta 1738 kot op. 4, iznašel ta žanr, razviden pa je tudi vpliv Antonia Vivaldija in, presenetljivo, angleške pesemske tradicije. Čeprav je Burgess še vedno slabo poznan, je bil nadarjen in inovativen skladatelj, čigar iskrivi koncerti, $k i$ se lahko izvajajo z orkestrom ali brez njega, si zaslužijo svoje mesto $v$ repertoarju.

Ključne besede: Henry Burgess mlajši, Henry Burgess starejši, angleška glasba, angleška pesem, Georg Friedrich Händel, orgelski koncert, Antonio Vivaldi

\begin{abstract}
Henry Burgess, Junior, published in 1743 the earliest known set of organ concertos by an English composer. These show strongly the influence of George Frideric Handel, whose organ concertos published as Op. 4 in 1738 invented the genre, but also reveal that of Antonio Vivaldi and - more surprisingly - the English song tradition. Though still little known, Burgess is a capable and inventive composer, whose sparkling concertos, performable either with or without orchestra, deserve a place in the repertoire.
\end{abstract}

Keywords: Henry Burgess (Junior), Henry Burgess (Senior), English music, English song, George Frideric Handel, organ concerto, Antonio Vivaldi

\section{The Organ Concerto in its English Context}

Eighteenth-century England has to its credit the creation, or at least a much more diligent and longer-lasting cultivation than elsewhere, of three distinct species of instrumental concerto, each of which responded to particular social and cultural conditions unique to the country. In comparison, the concerto for a single melody instrument (most often, a principal violin), which almost from the start of the century was by a long way the dominant type in continental Europe, led a patchier existence, being the province mostly of concertmasters or itinerant virtuosos, and was represented surprisingly sparsely in

The present article is written in memory of Nicholas Temperley (1932-2020), who many decades ago directed my studies at the University of Cambridge and was a lifelong champion of English music of the eighteenth and nineteenth centuries. I would like to acknowledge the kind assistance towards it given by Simon Fleming, Peter Holman, Peter Lynan and Andrew Woolley through the sharing of materials and comments made in private correspondence. 
the musical repertoire composed by native-born musicians and published in London or elsewhere in Britain.

The first of these new subgenres was the concerto commonly described in the titles of collections as being "in seven parts" or by a label such as "grand". ${ }^{1}$ This was a direct descendant of the characteristic Roman type of concerto (represented by such figures as Arcangelo Corelli, Antonio Montanari, Giuseppe Valentini, Giovanni Mossi and Pietro Locatelli) that was named after one of its components: the concerto grosso (or ripieno) comprising a string ensemble with doubled parts that provided reinforcement for, and contrast with, a "trio sonata" ensemble (concertino) featuring solo strings. It seems to have been Francesco Geminiani's orchestral arrangements of Corelli's solo violin sonatas, the first group of which appeared in 1726 from the London publisher William Smith, that transported the genre to English soil. ${ }^{2}$ Geminiani's own concerti grossi, Opp. 2 and 3, followed in 1732, giving rise to a continuous series of similar concertos by native composers that lasted up to at least the mid-1780s. In contrast, concerto grosso production, certainly in the form of published collections, ceased abruptly in Italy with Locatelli's Op. 4 (1736). Where the Roman and English forms of "seven-part concerto" crucially parted company from the very start was the societal context within which the works were intended for performance - and this divergence left its mark on the musical fabric itself. To generalize: a Corelli concerto was designed in the first instance for courtly, often ceremonial, surroundings and functions where house musicians customarily made up the concertino and supernumeraries, themselves also professionals, the ripieno. In contrast, a superficially similar English concerto by (say) Michael Festing or George Berg was oriented towards the world of public concerts, music clubs and even informal, purely recreational musicmaking. These settings observed fewer pre-set hierarchical distinctions, enabling musical amateurs to participate and, particularly in local music societies, even predominate. This was quintessentially "social" music where even a humble viola player might enjoy a brief moment of unexpected glory. It avoided extremes and sought to keep all the players, not merely their audience, happy.

The second characteristically English (or, rather, British) subgenre was a type of concerto where a pair of French horns was added to the generally four-part or seven-part string ensemble. These horns acted partly as "reinforcing" instruments adding warmth and richness to the middle of the texture, partly as soloists periodically playing lightly accompanied or even totally unaccompanied extended passages. The evocation of the traditional milieu of horn-playing, hunting in the countryside, was, however, now attenuated: what replaced it was the urban setting of horn-playing servants ceremonially marking the departures, arrivals and progress through the streets (or, very often, waterways) of

1 On the history and character of this concerto type, see Talbot, "From 'Sonate a quattro' to 'Concertos in Seven Parts"', 315-316. On occasion, the total number of parts may in fact exceed seven (this total generally being calculated on the basis of the number of partbooks rather than that of "real" parts), so that the number indicated in the title rises accordingly. This happens especially when wind instruments or a second viola part are included in the ensemble, as in Pieter Hellendaal's Six Grand Concerto's in Eight Parts, Op. 3 (1758), which adds a viola to the concertino.

2 Geminiani, Concerti grossi. 
their noble or high-bourgeois employers, which was a constant feature of the eighteenthcentury London soundscape. The foundational works for this new type can be identified as movements $3-5$ of the F major suite (HWV 348) and movements $1-2$ of the D-major suite (HWV 349) forming part of George Frideric Handel's Water Music (1717). ${ }^{3}$ Between the 1720s and the 1770s concertos with horns became ubiquitous in England: staple elements in public concerts, theatre music and music clubs alike - so popular, in fact, that some high-born members of orchestras belonging to the last-mentioned category were induced to take up the instrument despite its plebeian associations. ${ }^{4}$

The third - and historically most important and long-lived - novel type of concerto cultivated especially in Britain was that for solo organ and/or harpsichord. The introduction to a recent anthology of English keyboard concertos comprising thirteen works stretching chronologically from William Felton (1744) to William Russell (1810) estimates the total number of surviving compositions in the genre by British-born composers of that period at over 200. ${ }^{5}$ Its seminal works were the six making up Handel's Op. 4 (HWV 289-294), published in 1738 but originally composed (or arranged) as interval music designed to show off the composer's prowess as organist - plus, in places, improviser - in performances of his oratorios during the 1735 and 1736 seasons. ${ }^{6}$ Intriguingly, Handel may have been pipped to the post by the Newcastle organist and composer Charles Avison, who at a benefit concert for himself given in Hickford's Great Room in Panton Street, London, on 15 March 1734 played "a Concerto, the Solo Part to be perform'd upon the Harpsicord". This concerto is very likely identical with one published, together with a set of string parts (that for violoncello furnished with bass figures), in Newcastle in 1742 as the first of a pair, the partner work being a conventional concerto "for violins in seven parts".

One need not agonize too much over whether the organ or the harpsichord was the "preferred" choice of the composer in this and similar instances where both instruments are mentioned as alternatives (or even when only one of them is explicitly mentioned). For a start, the fact that most English organs - including the most easily transportable or quickly erectable among them - lacked pedalboards meant that from a strictly practical standpoint the two instruments were interchangeable. The organ possessed the advantage of greater strength and (usually) variety of tone - particularly useful in antiphonal dialogues with

3 The source material making up the Water Music is too complex even to summarize here, but the music's genesis is well described in Burrows, Handel, 77-78.

4 On the horn in eighteenth-century Britain and concertos employing horns in particular, see Talbot, "William Bates", 250-256.

5 English Keyboard Concertos, XIX.

6 Handel, Six Concertos for the Harpsicord or Organ. A very good concise introduction to Handel's organ concertos is Gudger, "Handel and the Organ Concerto".

7 Advertised in the Country Journal or The Craftsman of 9 March 1734. I am grateful to Simon Fleming for alerting me to this notice and to the first concerto of the publication cited in the next footnote.

8 Avison, Two Concertos. For prior appearances in England of the solo harpsichord in partnership with strings (albeit not in harpsichord concertos in a formal sense), see Lynan, "Organ Concerto", 162-163. I take this opportunity to thank Peter Lynan warmly for commenting on the present article in an earlier draft. 
an orchestral accompaniment. It obviously contrasted more sharply than a harpsichord with another harpsichord used as a continuo instrument, if one was present. It was also more decorous and magnificent in certain settings, such as oratorio performances. But it did not possess the ubiquity or transportability of the harpsichord and was less likely to be available for performances in most concert rooms or in domestic environments. It is clear that composers and performers took a pragmatic approach to the choice of instrument, as we should similarly do today. The size and composition of the accompanying ensemble could likewise vary greatly according to the availability of players and the size of the performing space, purely aesthetic considerations normally remaining subordinate.

On the surface, the typical solo part for a keyboard instrument resembles closely those of the "principal" instrument in any other type of solo concerto. Particularly if the solo instrument is a violin, it normally plays continuously throughout each movement, merging with the corresponding orchestral part during tutti sections. This unbroken line helps soloists to orient themselves and, if relevant, to direct the ensemble with the next best thing to an actual score. But there is an important difference between parts for keyboard soloists and those for players on any other kind of instrument, the harp excepted. It is abnormal for a keyboard player not to make concurrent use of both hands in the vast majority of bars, with the result that (a) the solo part has to be notated unvaryingly on systems of two staves, and (b) save in special circumstances, such as the start of a fugal exposition, the writing for it has to be in a minimum of two parts. One hardly needs to be reminded that, in Manfred Bukofzer's classic phrase, musical style during the Baroque period (and never more evidently than in the central decades of the eighteenth century) was governed by "a harmonic polarity between soprano and bass". 9 The austerity of twopart writing, normally with one part taken by each hand, dominated keyboard music over a wide temporal arc stretching from the late Baroque to the early Classical period. This textural sparseness was mitigated a little by the use of broken-chord figures or the sporadic insertion of notated or improvised inner lines and/or chordal notes, but it remained a constant characteristic. A correlation can perhaps be seen between the preference for a two-part texture and the rise in keyboard-playing among amateurs and especially the young, since having only one note to play at a time with each hand made not only for simplicity of execution but also for ease of reading the music on the page.

Following these principles, the solo parts of early harpsichord concertos usually took the form of short scores where the music on the upper staff was identical with the first violin part during tutti sections (with fragments of the second violin and/or viola parts added only where especially opportune and not technically too difficult) but independent during solo sections. In matching fashion, the left hand reproduced the continuo line (though often not its figures) in tutti passages but played independently elsewhere. ${ }^{10}$ Unlike in concertos

9 Bukofzer, Music in the Baroque Era, 11.

${ }^{10}$ Where figures are lacking in the keyboard part, a player (other than the composer) is not in a good position to play a full continuo harmonization during tutti passages unless - as becomes possible in a modern performance - he or she is reading from a score. The problem can be solved, as it was in Burgess's day, by employing throughout for the continuo an additional keyboard player reading from the figured Basso part. 
for melody instruments, there was no ever-present need to co-opt players from the rest of the ensemble for bass support or harmonic enrichment during solo passages, where the keyboard instrument could remain very literally "alone" if the composer wished to keep things simple. But this simple modus operandi left one important question unanswered: what to do when the soloist was asked to pause for a while - for example, during a slow movement entrusted to orchestra alone or in the intervals of "call-and-response" exchanges between soloist and strings. A surprising but commonly adopted solution was to write the unplayed notes into the short score as if for a tutti section, but then to add an explanatory cue such as "senza organo". The virtue of this seemingly self-contradictory practice was that it indicated clearly to the keyboard player the location of pauses in a performance "with accompaniments" (i.e., with orchestra), while at the same time providing a complete and, more importantly, continuously running musical text for anticipated performances without orchestra. One should remember that throughout the eighteenth century there was immense tolerance for "reduced" scores of every kind, right down to the versions of vocal melodies scored for unaccompanied recorder or traverso that were used as space-fillers in song collections. ${ }^{11}$ At the humbler levels of music-making accessibility, practicality and cost were factors always likely to outweigh scrupulous attention to completeness and fine detail. Contrary to modern expectation, orchestra-less performances of eighteenth-century keyboard concertos, provided that their composers foresaw that possibility and catered for it in the musical material they committed to print, are able to produce a good (even if not ideal) effect via intelligent solutions. For example, call-and-response dialogues, even though their antiphony is not readily reproducible on a single instrument, can often be simulated effectively through alternations of dynamic level, registration or manual.

There is no space in this article for a more detailed general study of the keyboard concerto in eighteenth-century Britain - a subject that has already accumulated quite a substantial literature, including an information-packed doctoral thesis by the editor of the anthology cited earlier. ${ }^{12}$ We now move on to consider the article's little-known, and in my view under-appreciated, protagonist, starting with his homonymous father, who was similarly named Henry Burgess.

\section{Henry Burgess, Senior, and Henry Burgess, Junior}

Neither Burgess, father or son, has been well served by the lexicographical tradition. The only actual dictionary articles (as opposed to catalogue entries) specifically dedicated to them are the two brief ones found in the biographical dictionary of figures connected with London theatres compiled between 1973 and 1993 by the team of Highfill, Burnim and Langhans, which, conforming to the house style of this otherwise admirable compilation,

${ }^{11}$ The concertos by Burgess that are the subject of this article are an excellent case in point, for the surviving examples of the first edition, which lack the complementary orchestral parts (even though the prospectus inviting subscriptions mentions them), greatly outnumber those of the second edition, which include these "accompaniments".

12 Lynan, "English Keyboard Concerto". 
hardly ever reveals the source of information. ${ }^{13}$ What follows is therefore largely pieced together from small pieces of evidence culled from a multitude of sources, some of which have not been known about before.

The mainstay of the career of the elder Henry Burgess was his membership of the King's (or Royal) Band of Musicians, to which he was admitted principally as a keyboard player on 28 September 1723 in succession to William Babell, who had died five days earlier. ${ }^{14}$ Coincidentally or not, Babell's musical style, as displayed in his keyboard compositions as well as in the occasional flamboyant passages for solo harpsichord inserted into his ensemble music, prefigures in certain respects that of the younger Henry - for instance, the two men share an Italianate predilection for sequential passage-work and motor rhythms - and it would have been very natural if, through a connection to the Royal Band that Henry, Senior, would soon join, Babell acted as a formative influence on his son.

Nothing certain is known about the elder Henry's earlier life. Both he and his son appear to have been parishioners of St Martin-in-the-Fields, Westminster, where the latter was christened and lies buried. A large number of parishioners with a surname spelled "Burgis" or "Burges" (but not "Burgess"!) are found in registers of the same church for the seventeenth century. It seems that the original written form of the family's surname - the one that predominates in church records - was "Burgis", whereas "Burgess" (which looks and sounds more elevated, since it can denote a minor civic official) was very possibly a variant form adopted, initially by the elder Henry, for professional reasons. Whether this Henry was born within the London-Westminster conurbation or moved there only at a later stage and who his parents were are things awaiting discovery. The most likely decade for his birth was the 1690s.

The marital life of Henry Burgess, Senior, appears to have been complex, not to say confusing, since each of his three known wives was called Mary. The first Mary was the mother of Henry, Junior ("Henry Burgis of Henry \& Mary"), born on 11 October 1718 and baptized at St Martin-in-the-Fields on 19 October, ${ }^{15}$ and of his sister Isabella ("Issabella Da[ughte]r of Henry Burgis \& Mary in Dean Street Holborn"), baptized at St Andrew, Holborn, on 2 February $1721 / 1722 .{ }^{16}$ I have so far not managed to ascertain with certainty by trawling through genealogical websites who this first Mary was, nor when and where she married Henry. The first candidate to consider is a Mary Phillips with whom a Henry Burges concluded a so-called clandestine (or "Fleet") marriage on 4 August $1703 .{ }^{17}$ His

${ }^{13}$ Highfill, Burnim and Langhans, Biographical Dictionary, 2:418.

${ }^{14}$ Daub, "Music at the Court of George II", 326.

${ }^{15}$ Record set "Westminster, London, England, Church of England Baptisms, Marriages and Burials, 1558-1812". The digitized document from which this information is taken and all other web references cited in this article were verified via access on 20 January 2021.

${ }^{16}$ Record set "London, England, Church of England Baptisms, Marriages and Burials, 1558-1812". The composite form (1721/1722) given for the year reflects the fact that nearly all English church registers up to and including 1752 follow the Style of the Incarnation, in which the days between 1 January and 24 March are assigned to the outgoing, not the incoming, year. The later year is of course the one used today. Isabella, who died in 1803, married in 1759 a well-known bookseller on the Strand, Thomas Wilcox.

${ }^{17}$ Record set “London, England, Clandestine Marriage and Baptism Registers, 1667-1754”. Weddings 
address is given as "St Pauls All[e]y Near The St Pauls", hers as "Love Lane". The main obstacle to accepting this identification is the early date of the wedding, which leads one to ask why no children apparently arrived between then and 1718 and why no musical activity on Henry's part during the same period has come to light. A more promising candidate is a Mary Jones of the parish of St James, Piccadilly, who married a Henry Burgis of St Clement Dane at Gray's Inn Chapel (the chapel attached to this Inn of Court) on 9 May $1714 .{ }^{18}$ But even assuming that this Mary had actually been christened at the fashionable Westminster church of St James and had not moved into the parish from outside, there is, alas, a bewildering plethora of identically named bridal candidates of a suitable age to choose between. ${ }^{19}$ As for the Henry in question, he cannot be pinned down any more firmly than she.

Whoever she was, the first Mary had evidently died by 24 May 1725, for on that day her successor, a Mary Ardern who lived, like her bridegroom, in the parish of St George, Hanover Square, married Henry Burgis at St James, Piccadilly. ${ }^{20}$ Their first and perhaps only child, another Mary, was laid to rest at the same church on 9 February 1727/1728. The choice of a church wedding in a prosperous neighbourhood perhaps reflects an upswing in Henry's fortunes at this time.

The third Mary, daughter of a Thomas Wormsley and described as "spinster", married her fellow parishioner "Henry Burgess, Musician of St. Giles's [St Giles-in-the-Fields] wid[owe]r" at the Fleet Prison on 23 July $1741 .{ }^{21}$ The choice of a clandestine wedding might seem a regression after the elegance of St James, but there are so many possible reasons for it that it is best not to speculate. The union does not seem to have produced further children. After Henry's death this Mary acted as his executrix for his will, and inherited practically the whole of his estate, since the younger Henry was left merely his father's music, Isabella a shilling and a gold ring and another son, Thomas, whose identity is not clarified by other documentation, a shilling and a pair of ornamental buttons. ${ }^{22}$ The will was drawn up on 7 March 1764. It left the executrix free to choose a site of burial, and when Henry died just over a year later, on 17 March 1765, he was interred at St Paul, Covent

conducted within London's Fleet Prison or in its vicinity were able, through an obscure legal loophole, to offset their undeniable stigma by circumventing many of the potential drawbacks of, or obstacles to, a conventional church wedding. They were secret (useful for a person who wished to succeed to an inheritance that would be withheld if he or she married, or for a bigamist), entailed no posting of banns or granting of a licence, required no parental consent in the case of minors, could be arranged very quickly and were much cheaper than church weddings. Unsurprisingly, they were at certain times the choice of a majority of Londoners.

${ }^{18}$ The wedding is recorded in Foster, Register of Admissions, 59.

${ }^{19}$ For instance, there were three infants christened as Mary Jones at St James during 1694-1696.

${ }^{20}$ Record set "Westminster, London, England, Church of England Baptisms, Marriages and Burials, $1558-1812$ ".

${ }^{21}$ Record set "London, England, Clandestine Marriage and Baptism Registers, 1667-1754".

${ }^{22}$ Record set "England \& Wales, Prerogative Court of Canterbury Wills, 1384-1858" (which includes a digital reproduction of the original archival copy in Kew, The National Archives, PROB 11/906/305). Thomas could, perhaps, be identical with a "Thomas Burgess, Drawing Master" resident in Duke Street, Lincoln's Inn Fields, listed on p. 6 of Thomas Mortimer's Universal Director of 1763 (see later, note 26). 
Garden. His connection, presumably by birth, with a different parish was recognized, however, by his description in the burial register as "Henry Burgiss from St. Martin in y Fields". ${ }^{23}$ Two days later, the will was proved. The widow is probably the same person as the "Mary Burgis" who was buried at St Paul on 30 August 1779.24

A few landmarks in the elder Henry's otherwise rather uneventful life can be identified. In June 1730 he competed unsuccessfully for the vacant organist post at St Mary-at-Hill (to which Henry Duncalf succeeded). ${ }^{25}$ No further applications of a similar kind seem to have been made by him. His major occupation "on the side" was almost certainly the private teaching of music in the form of harpsichord (and perhaps also singing) lessons: we find both him and his son listed in 1763 among the "Masters and Professors of Music" (respectively, as "Burgess, Henry, senior, one of his Majesty's Band. Brownlow-street" and "Burgess, Henry, junior. Great Queen-street, Lincoln's-in-fields") in Thomas Mortimer's directory of professional men of various kinds (a sort of Yellow Pages ante diem) ${ }^{26}$ Like so many other minor English musicians of his time, Henry made a small and intermittent contribution to song composition. One of his earliest songs must have been "Love's a dream of mighty treasure" (separately titled The Illusion), which he contributed to the first volume (1729) of the publisher John Watts's six-volume song anthology The Musical Miscellany. ${ }^{27}$ The elder Henry's sole substantial publication was a collection of harpsichord pieces in a "familiar" style (i.e., one suitable for domestic recreation, thus not technically challenging), which John Johnson brought out - and may have commissioned, since he financed the operation - at some point in the mid $1750 \mathrm{~s} .^{28}$ These competently written and indeed rather pleasing compositions, which group the individual movements into little suites, would be well worth publishing some day, even if only in a facsimile edition.

The elder Henry raised his profile a little among his peers by becoming, in 1738, a founder member and director of the benefit society for professional musicians originally known as the Fund for the Support of Decayed Musicians or Their Families, which later changed its name, after receiving a royal charter, to the Royal Society of Musicians, still going strong today. ${ }^{29}$ His son joined in the following year. The importance of this membership for both men was that it placed them within a collegial network providing not only

${ }^{23}$ Record set "Westminster, London, England, Church of England Baptisms, Marriages and Burials, 1558-1812".

${ }^{24}$ Hunt, Registers of St. Paul's Church, 5:117.

${ }^{25}$ Dawe, Organists of the City of London, 85. Dawe leaves it open whether the applicant was the elder or the younger Henry Burgess, but since the latter was aged only twelve at the time, it stretches credibility to imagine that it was he, especially when nothing more is heard of him until 1738.

${ }^{26}$ Mortimer, Universal Director, 32.

${ }^{27}$ Musical Miscellany, 1:129.

${ }^{28}$ Burgess, Sr, Collection of Lessons. The phrase "for John Johnson" (rather than "for the author and sold by John Johnson") appearing in the imprint on the title page defines in customary language which party paid for the engraving.

${ }^{29}$ On the early history of this society, see especially Drummond, Royal Society of Musicians; and Matthews, Royal Society of Musicians. "Decayed" in the society's original name refers not only to infirmity but also to hardship of any kind. 
practical support if needed but also news and recommendations regarding professional opportunities.

We move on now to Burgess fils. For convenience, I will give his forename from this point onwards as "Harry", the colloquial form of Henry by which he was popularly known, at least in his youth. Between the notice of his baptism and the year 1738 there is no trace of him anywhere. His sure command, from the very start, of all the basic skills of composition - from melody, harmony and counterpoint to form and instrumentation implies expert, sustained teaching in childhood and adolescence. Very likely, his father instructed Harry in the first rudiments, but the son probably received more advanced and systematic tuition from a respected pedagogue such as Johann Christoph Pepusch, who happens, perhaps not coincidentally, to have been a subscriber to both of Harry's first two published collections: the organ concertos and the volume with cantatas and songs.

Harry appears to have made his public début as the contributor of two songs to an afterpiece, The Coffee House (by the dramatist James Miller), that opened at the Drury Lane Theatre on 26 January $1738 .{ }^{30}$ Most of the songs used in the production, however, were by Henry Carey (1687-1743), a prolific poet, singer and composer (especially of songs, but also with more ambitious works to his credit), who at the time served Drury Lane as a kind of unofficial house composer. Harry may well have been Carey's protégé and even assistant: one cannot easily imagine the older man to have been Harry's actual composition teacher, but he was doubtless a mentor in the domain of song composition.

On 17 January 1739 Harry reappeared at Drury Lane in "a new Concerto, composed and performed on the Harpsichord by Mr Henry Burgess Jr. with Accompanyments". There are similar reports of his concerto-playing (always on harpsichord, not organ) on 19 January, 5 March, 3 May, 5 May and 22 May 1739. A report in the London Daily Post and General Advertiser appearing on the same day as the last-mentioned performance notes that the concerto was used on that occasion "for the second music" preceding George Farquhar's comedy The Beaux Stratagem - in other words, as the second introductory piece of orchestral music preceding the overture to the play itself - and this was probably the customary place for concertos at Drury Lane.

A witness to these performances was the organist and, later, historian Charles Burney (1726-1814), who in his General History included among a group of leading instrumentalists of the time "little Harry Burgess at the harpsichord in Drury-lane, where, for second-music, he often played concertos, generally of his own, as clean and unmeaning as on a barrel". ${ }^{31}$ By "barrel" Burney means the barrel of a musical clock, an allusion to the motor rhythms that dominate the fast movements of the concertos. His epithet "clean and unmeaning" pays tribute to Harry's virtuosity but disparages his

${ }^{30}$ The main source of information on eighteenth-century theatrical productions in London is the London Stage, 1660-1800, a multi-volume, chronologically organized calendar of plays and similar productions mainly compiled from playbills, newspapers and theatrical diaries. In the interest of saving space, it may be assumed that where no original source is given with regard to individual productions and their participants the details can be verified from this authoritative reference work.

${ }^{31}$ Burney, General History of Music, 4:664. 
alleged lack of musical expression. In early life, before embracing the aesthetic ideals of the Enlightenment and reacting strongly against those of the previous generation, the historian had been enamoured of this typically Italian style, confessing elsewhere in his History: "I remember in the early part of my life being a dupe to the glare and glitter of this kind of Tinsel [a reference to Babell's keyboard music]; this poussiere dans les yeux [dust in one's eyes], which Mr. Felton [William Felton, most prolific of the English organ concerto composers], and other dealers in notes, et rien que des notes [notes, and nothing but notes] continued" - before he, Burney, underwent conversion to the realm of "taste, expression, and light and shade". ${ }^{32}$

Burney fills out his description of Harry's playing a little in two other writings. His so-called memoirs - remnants of preparatory jottings for a finished work of that type that was never achieved - contain a reference, dating from the mid-1740s, to "Burges, who had a very neat finger that never failed him in the common passages of w[hi]ch his concertos were composed". 33 "Common" means here "ordinary", with a soupçon of "hackneyed" - actually, rather fair comment on the fact that Harry's basic musical ideas are in themselves generally less original and striking than his development and treatment of them. There is also a passing reference to Harry embedded in an anonymous entry for the blind Welsh harpist Thomas Jones that Burney wrote during the years leading up to his death for the Cyclopaedia of Abraham Rees. ${ }^{34}$ As he so often did, notwithstanding his professed contempt for Sir John Hawkins, the other great English music historian of the late eighteenth century (who, incidentally, does not mention Harry in his writings), Burney closely paraphrases his rival's account of the given subject, ${ }^{35}$ but then embellishes its description of Cuper's Gardens (newly established pleasure gardens in Lambeth where Jones was a star performer, and which had just acquired an organ specially built by Richard Bridge) by adding that the new instrument "was played by little Harry Burges, the harpsichord-player at Drury-lane, with his usual unmeaning neatness". ${ }^{36}$

Burney implies there that Harry not only visited Drury Lane to perform his concertos but also played regularly at that theatre as house harpsichordist, which would entail at the very least the additional duties of a continuo accompanist. In the absence of documentation providing a list of the theatre's personnel during this period, no definite answer one way or the other can be given. Harry's known, datable performances at Drury Lane, which are doubtless fewer than the total number that actually took place, number no more than the five already mentioned, all situated in the 1738-1739 season, plus one from 1745 shortly to be discussed. I currently favour the view that his presence at Drury Lane was occasional rather than regular, and coincided primarily with his appearances there as a soloist in a context where the participation of a separate continuo harpsichordist (probably

${ }^{32}$ Ibid., 4:649.

${ }^{33}$ Klima, Bowers and Grant, Memoirs of Dr. Charles Burney, 46.

${ }^{34}$ Rees, Cyclopaedia, 19:[358].

${ }^{35}$ Hawkins, General History, 5:357 (footnote).

${ }^{36}$ On the short but lustrous history of Cuper's Gardens, see Wroth, London Pleasure Gardens, 247-257. 
the actual house harpsichordist!) was always required - but I would not be surprised to be proved wrong.

We next meet Harry playing, and apparently inaugurating, the organ at Cuper's Gardens on 16 June 1741. Playbills for the event proclaim: "a new grand concerto for the organ by the author, Mr. Henry Burgess, junior, of whom it may be said without ostentation that he is of as promising a genius and as neat a performer as any of the age". ${ }^{37}$ This event is interesting for being the earliest to feature a performance by Harry on organ of one of his keyboard concertos. Concertos for organ were by then not absolute novelties outside the context of performances of Handel choral works - during 1739 organ concertos were given pride of place in a series of monthly subscription concerts by leading musicians at Hickford's Room in Brewer Street - but the occasion in 1741 may well constitute the earliest public performance in London of an organ concerto by a named composer other than Handel. Harry appeared in two similar concerts at Cuper's Gardens in July 1741. Apart from the fact that the proprietress of Cuper's Gardens, Mrs Evans, subscribed in 1743 for three copies of Harry's concertos (purchasing multiple copies obviated the need to copy out band parts by hand), which is indirect evidence that their performance continued, presumably still with Harry as soloist, there is no further evidence of his presence there. I have a suspicion, however, that a patriotic song, "Rouse, Britons, Drive the foe" (Harry's setting of a text excoriating the Bourbon monarchy and its fleet, which was published in 1746 in the second volume of the song anthology Calliope or English Harmony), is connected with celebrations of the victory over the Jacobites at Culloden that were held at Cuper's Gardens on 14 August $1746 .{ }^{38}$ If so, the association may have continued for several years.

Harry finally decided to consolidate the reputation he had earned with his keyboard concertos by committing six of them to print. He chose the common route of initially publishing them privately by subscription, probably already expecting to be able to sell on the engraved plates to his chosen stockist at a later stage. The prospectus he placed in the Daily Advertiser of 11 January 1743 reads as follows:

\section{MUSICK}

PROPOSALS for printing by SUBSCRIPTION, with the Instrumental Parts, as they were perform'd at the Theatre Royal in Drury-Lane, by the Author, HENRY BURGESS jun. I. The Price to Subscribers is Half a Guinea; ${ }^{39}$ Five Shillings to be paid at the Time of Subscribing, and the Remainder on the Delivery of the Book. II. The Work will be ready to deliver to the Subscribers in February next. Subscriptions are taken in by the Author, in Brownlow-Street, near Drury-Lane; and at Mr. Walsh's, in Katherine-Street in the Strand.

${ }^{37}$ Ibid., 249-250.

38 Calliope or English Harmony, 2:76-77.

39 The gold coin known as a guinea was worth twenty-one shillings. A half-guinea therefore equalled ten shillings and sixpence. It was normal for deposits paid by subscribers to be set at the level of about half the total cost. 
The publication took a little longer than promised to be delivered, perhaps because subscriptions were initially slow coming in, thereby delaying the start of engraving. But Walsh was finally able to announce publication of the set in the London Daily Post and General Advertiser of 28 March 1743.

RISM lists eight known library examples of this first edition. ${ }^{40}$ All are preserved, and may well have been purchased, simply as a keyboard score. The title page reads:

SIX | CONCERTOS | for the | Harpsichord or Organ | Compos'd by | M. ${ }^{\mathrm{r}}$ HENRY BURGESS Jun. ${ }^{\mathrm{r}}$ | London. Printed for the Author. | Sold by I. Walsh in Catharine Street in the Strand.

The keyboard part has no heading identifying it as such, but perhaps one would have been considered redundant, given the part's notation on two staves.

At some later stage Harry passed on the plates to Walsh, who made no visible alterations at all to the engraved plates of the keyboard part except for the replacement of the original title page by a new one reading:

SIX | CONCERTOS | for the | ORGAN and HARPSICHORD, | also for VIOLINS \& other $\mid$ Instruments in 5 Parts $\mid$ Compos'd by $\mid$ M. $^{r}$ Hen. Burgess Jun. ${ }^{r} \mid$ London. Printed for J. Walsh in Catherine Street in the Strand. ${ }^{41}$

One notes here the reversal of the order of harpsichord and organ, implying that the organ is now considered the primary instrument (matching the composer's move from harpsichord to organ in his own public performances), and the new mention of the instrumental accompaniment. ${ }^{42}$ Walsh is now identified as the publisher through the replacement of "sold by" by "for". The main set of parts comprises Violino Primo, Violino Secondo, Tenore (a faux-Italian form of the traditional English word "Tenor", denoting a viola) and Basso. It is likely that the Basso part was normally sold, as was customary, in duplicate, which could explain why the "other instruments" run to five parts, according to the title page. In addition, the parts include three supplementary ones printed rather messily on half-sheets. These are for "Hautboy Primo", "Hautboy Secondo" and "Basso Ripiano" [recte, Ripieno], which are all obbligato parts required for Concerto $\mathrm{V}$ only. The Basso part is quite copiously figured throughout.

40 "RISM Catalog", ID no. 990007604. The holding libraries are: Pendlebury Library of Music, Faculty of Music, University of Cambridge (GB-Cpl); The British Library (GB-Lbl); Oxford, Bodleian Library (GB-Ob); Winchester, Hampshire Record Office (GB-WCr); Cambridge, Harvard University, Harvard College Library (US-CA); Chicago, The Newberry Library (USCn); Washington, The Library of Congress, Music Division (US-Wc); and Colonial Williamsburg Research Department, historical collection (US-WGw).

${ }^{41}$ If Harry did not renege on his promise to supply subscribers with a set of instrumental parts (always a possibility), it seems likely that the instrumental parts likewise remained unaltered from the first edition.

${ }^{42}$ Peter Lynan raises, in private correspondence, the possibility that Walsh's phrase "the Organ and Harpsichord" refers in fact not to alternative instruments for the solo part but to complementary instruments performing, respectively, concertante and continuo roles. 
RISM lists only two known library examples of this second edition. ${ }^{43}$ Rather perversely, this edition contains the expected list of subscribers, whereas the first edition apparently does not. This list, which contains seventy-eight names of subscribers, a few among whom (such as the music dealers John Simpson and John Johnson and the pleasure garden proprietress Mrs Evans) took multiple copies, repays careful perusal, since it contains much interesting information of biographical relevance. Table 1 identifies the major categories of subscriber identifiable, albeit with a degree of caution, from the list, which sometimes adopts unusual spellings (normalized in the table) or omits the forename. Where subscribers belong to more than one category, their names are repeated. Seventyeight is a rather disappointing number for even a debutant musician to achieve, although probably sufficient to cover costs.

Table 1

Description by category of the subscribers to the Six Concertos by Henry Burgess, Jr (1743)

\begin{tabular}{|c|c|}
\hline Female pupils & $\begin{array}{l}\text { Miss Bellamy, Miss Sarah Crowder [= Crowley?], Miss } \\
\text { Demorin, Miss Derisme, Miss Dixon, Miss Gibbon, Misses } \\
\text { Susanne and Madeleine Guinand, Miss Mayne, Miss Rigail, } \\
\text { Miss Simons }\end{array}$ \\
\hline Harpsichord makers & Jacob Kirkman, Joseph Mahoon \\
\hline Huguenots & $\begin{array}{l}\text { Miss Demorin, Miss Derisme, Misses Susanne and Madeleine } \\
\text { Guinand, Cyprien Rondeau, Miss Rigail }\end{array}$ \\
\hline King's Band members & Joseph Abington, Arthur Bradley, John Hudson, Thomas Jones \\
\hline $\begin{array}{l}\text { Men of independent } \\
\text { means }\end{array}$ & $\begin{array}{l}\text { Daniel Bayley, James Dopson, Timothy Dewell, Sir Philip } \\
\text { Hall, James Harris, Joseph Hiscox, James Hatley, Abel- } \\
\text { Johnston Ketelbey, George Lynn, Thomas Masterman, } \\
\text { Richard Warner }\end{array}$ \\
\hline Merchants & Cyprien Rondeau, John Albrecht Vassmer \\
\hline Music dealers & John Johnson (6 sets), John Simpson (2 sets) \\
\hline Organists & $\begin{array}{l}\text { John Bennett, John Cary (?), Thomas Chilcot, Dr Maurice } \\
\text { Greene, Samuel Howard, William Jackson, Johann Christoph } \\
\text { Pepusch, Nelme Rogers, William Savage, "Mr Trevor" } \\
\text { [= John Travers?], James Vincent }\end{array}$ \\
\hline Professional men & $\begin{array}{l}\text { William Dodd (army captain), Richard Hamilton (surgeon), } \\
\text { Henry Watson (surgeon) }\end{array}$ \\
\hline Pupils of Pepusch & $\begin{array}{l}\text { John Bennett, Samuel Howard, William Savage, "Mr Trevor" } \\
\text { [= John Travers?] }\end{array}$ \\
\hline
\end{tabular}

43 "RISM Catalog", ID no. 990007605. The holding libraries are: GB-Lbl and Durham, The Cathedral Library (GB-DRc). The digitized copy in the British Library (g.251.b) is the base text used in this article for analytical discussion and music examples. 
Table 1

(continued)

\begin{tabular}{|l|l|}
\hline RSM members & $\begin{array}{l}\text { Joseph Abington, John Barnard, John Beard, Thomas Barrow, } \\
\text { Arthur Bradley, Richard Carter (?), Thomas Chilcot, Maurice } \\
\text { Greene, John Hudson, Thomas Jones, Thomas Lowe, "Mr } \\
\text { Trevor" [= John Travers?], James Vincent }\end{array}$ \\
\hline Singers & $\begin{array}{l}\text { John Beard, Thomas Barrow, Mrs. [Kitty] Clive, Mrs Collett, } \\
\text { Thomas Lowe }\end{array}$ \\
\hline
\end{tabular}

Many subscribers are not identifiable with certainty. Question marks in the table identify those persons who would be of interest if correctly identified but whose inclusion should for now be regarded only as speculative. The first thing to strike the reader is the complete absence of members of the nobility: the best the list can offer is a knight (Sir Philip Hall). This lacuna at the top of the social spectrum is typical for the subscription lists of composers who were organists or teachers and lacked courtly connections or noble patrons and employers. On the other hand, there is a good sprinkling of what I have termed "men of independent means", their status conventionally signalled by the title "Esquire". Many of these were provincial landowners who paid seasonal visits to London and had the inclination and means to exercise patronage on a small scale via subscriptions to the publications of favoured musicians. Most of the female subscribers whose surnames are prefaced merely by "Miss" (where a forename is missing, one assumes that the eldest unmarried daughter in a family is meant) must have been pupils of Harry, although one or two could have been well-off spinsters happy to support a young musician. ${ }^{44}$ Predictably, the overlapping categories of organists, members of the future Royal Society of Musicians and members of the King's Band, all with their individual collegial loyalties, collectively form the numerically strongest group. Lastly, one should mention the presence of several members of London's Huguenot community, whose wealthier families lived in and around Soho and took a keen interest in cultural pursuits, including music.

On 9 September 1743, according to an advertisement in the London Daily Post and General Advertiser for the day before, Harry played a concerto on the organ at the Castle Tavern in Paternoster Row during a concert whose main item was William Boyce's serenata Solomon; whether this was a new concerto or one of the published ones is not stated. Then on 3 April 1745 he returned to Drury Lane to play an organ concerto at a performance of Thomas Arne's opera Alfred the Great. These are the last two documented public performances by him. In fact, I have been able to trace no later biographical references except what can be gleaned from his two subsequent publications, his father's will, the record of his burial and of course Burney's retrospective comments. He does not seem to have retreated to the provinces, which is the commonest explanation for the abrupt disappearance from view of London musicians. The simplest scenario is perhaps

${ }^{44}$ The strongly "gendered" character of keyboard playing in the eighteenth century and its effect on subscription to publications are explored in fascinating detail in Fleming, "Gender of Subscribers", especially 103-109. 
the most credible: he grew tired of, or experienced some impediment towards, high-profile public performance, and as a bachelor (it appears), he made enough to live on from a combination of teaching, composition and perhaps occasional jobs such as accompaniment or music copying.

His Collection of English Songs and Cantatas, announced by Walsh in the General Advertiser of 4 May 1749, is a composite publication of a kind typical for England at that time, comprising two cantatas (a name freely awarded by English composers to almost any relatively elaborate multi-sectional song that included at least one section styled as a recitative), six strophic songs and a final "lesson for the harpsichord". This, too, was published by subscription, the list this time reaching a healthier total of 126 names; the reappearance of several names belonging to persons who, or whose close kin, had subscribed earlier to the concertos shows that Harry had acquired a loyal following. The cantatas receive quite favourable comment in Paul Rice's catalogue of British cantatas of the eighteenth century, which speaks of "attractive melodies" that are only slightly compromised by occasionally awkward word-setting. ${ }^{45}$

Harry's "swan song" is unexpected in nature: a dated (1781) and privately published ("for the Author") collection of nine trio sonatas for two violins, cello and continuo. The print is preserved uniquely in the British Library, and unfortunately lacks its thoroughbass part. ${ }^{46}$ Since this is one of the very last trio sonata collections to be published in an original edition in England - or anywhere else - it invites inspection. (Unfortunately, this is impossible at the time of writing on account of a temporary closure of the library.) Some trio sonatas published this late in the eighteenth century are fully "Classical" in their musical language, and it would be interesting to find out whether Harry's style, already galant to a certain degree in the 1740 s, evolved further in the succeeding decades.

The final event in Harry's life, his burial, took place at St Martin-in-the-Fields on 2 April $1786 .{ }^{47}$ It seems to have occurred in total obscurity: I have found no press notices, let alone obituaries, referring to it.

Leaving aside simple bibliographical references (which often confuse father and son), the nineteenth century and the first part of the twentieth are a near-void with regard to both Harry's biography and the reception history of his music. The first stirrings of interest that I have discovered emerge in a chapter on concert life in England written jointly by H. Diack Johnstone and Rosamond McGuinness for the Blackwell History of Music in Britain (1990), where the following critical assessment of the concertos is made:

They [the concertos] are notable chiefly for their brevity, but such compression is hardly displeasing when form and matter are so well matched. Concertos 1, 3 and 4 in particular have a strong Italian flavour suggesting Vivaldi. Elsewhere there are passing

${ }^{45}$ Rice, Solo Cantata, 121-123.

${ }^{46}$ GB-Lbl, g.251.a. The example lacks the thorough-bass part, but it is unclear from the library's catalogue whether this is a duplicate of the cello part with added figuring, exactly the same as the cello part or an independent part.

${ }^{47}$ Record set "Westminster, London, England, Church of England Baptisms, Marriages and Burials, 1558-1812”. 
hints of the galant style which was soon to become fashionable, and no. 5 has oboes in the accompaniment as well as strings. ${ }^{48}$

I would not dissent from anything in this admirable characterization except to qualify the remark about brevity. The first five concertos possess ritornello-form Allegro movements in common time that run to $96,118,82,113$ and 110 bars, respectively. Granted, the other movements (and all the movements, in the case of Concerto VI) are more modestly scaled, but the ritornello-form movements amply demonstrate Harry's command of complex and large-scale design.

A longer account of the concertos appears in Peter Lynan's doctoral thesis, cited earlier, which repeats the contestable statement about the shortness of their ritornelloform movements. ${ }^{49}$ Noting correctly that Harry's organ concertos, in performance as well as in publication, were pioneering works for an English composer, Lynan rightly draws attention to their Venetian-style (i.e., "Vivaldian" in the broadest sense) use of ritornello form and their clear tonal plans, as well as the presence of solo (as distinct from doubling) oboes in the third movement of Concerto V. I would question, however, his statement that the tonic-dominant-relative-tonic plan for ritornellos is "unaltered from one concerto to another", since Concerto IV has an additional ritornello in the subdominant key, Concertos I and IV one in the mediant key and Concerto II even one in the supertonic key, while Concerto V reverses - as commonly happens in the minor mode - the order of dominant and relative keys. Moreover, as an extra tonal ingredient, there is a striking major-minor shift in the opening ritornello and two of its subsequent iterations in the first movement of Concerto II. Lynan also remarks a little negatively on the quick movements' "heavy reliance on almost continuous semiquaver episodic passage work", the "predictability of [Burgess's] solo material" and "a certain similarity between some of the allegro themes". All these observations are factually incontrovertible, but one has some latitude in deciding whether these features arise from a simple deficit of imagination or are conscious compositional choices with compensatory benefits.

The second volume of Lynan's thesis contains a thematic catalogue with full incipits of English organ concertos, including Burgess's. ${ }^{50}$ Incipits for the latter are also listed in Owain Edwards's slightly later catalogue of English eighteenth-century concertos for all instrumental combinations. ${ }^{51}$

To date, only one of Harry's concertos has been published in a modern edition: Concerto V, edited by Francis Hopper. ${ }^{52}$

48 Johnstone and McGuinness, "Concert Life in England I", 65.

${ }^{49}$ Lynan, "English Keyboard Concerto", 1:84-85.

${ }^{50}$ Ibid., 2:11-14.

${ }^{51}$ Edwards, English Eighteenth-Century Concertos, 62-64.

${ }^{52}$ Burgess, Jr, Concerto $V$. At the time of writing, I am working on a critical-cum-practical edition in separate volumes of all six concertos. 


\section{The Six Concertos}

\section{Basic Details}

Analytical discussion of Harry's concertos can conveniently start with a close reading of the data in Table 2, which summarizes some important elements of their content.

Table 2

Basic details of the Six Concertos by Henry Burgess, Jr

\begin{tabular}{|c|c|c|c|c|}
\hline No. & Key & Heading, Metre & Structure & Notes \\
\hline \multirow[t]{3}{*}{$\mathrm{I}$} & \multirow[t]{3}{*}{$\mathrm{G}$} & 1. Allegro, ${ }_{4}^{4}$ & ritornello form & \\
\hline & & 2. Largo Andante, $\frac{3}{4}$ & unitary form & $\begin{array}{l}\text { In E minor. Leads to a } \\
\text { Phrygian cadence. }\end{array}$ \\
\hline & & 3. GIGA, Presto, $\frac{6}{8}$ & $\begin{array}{l}\text { binary form with } \\
\text { introduction }\end{array}$ & \\
\hline \multirow[t]{4}{*}{ II } & \multirow[t]{4}{*}{$\mathrm{Bb}$} & 1. Allegro, ${ }_{4}^{4}$ & ritornello form & \\
\hline & & 2. Andante, ${ }_{4}^{3}$ & $\begin{array}{l}\text { binary form, only first } \\
\text { section repeated }\end{array}$ & $\begin{array}{l}\text { In G minor. Has brief } \\
\text { Adagio conclusion } \\
\left(\text { in } \frac{3}{2}\right) \text { leading to a } \\
\text { Phrygian cadence. }\end{array}$ \\
\hline & & 3. FUGUE, Allegro, ${ }_{4}^{4}$ & concertante fugue & Has Adagio conclusion. \\
\hline & & 4. Allegro, $\frac{3}{8}$ & $\begin{array}{l}\text { binary form with } \\
\text { introduction }\end{array}$ & \\
\hline \multirow[t]{3}{*}{ III } & \multirow[t]{3}{*}{ A } & 1. Allegro, ${ }_{4}^{4}$ & ritornello form & \\
\hline & & 2. Largo, $\frac{3}{4}$ & $\begin{array}{l}\text { unitary form with } \\
\text { introduction }\end{array}$ & $\begin{array}{l}\text { In F\# minor. Has brief } \\
\text { Adagio conclusion } \\
\left(\text { in } \frac{3}{2}\right) \text { leading to a } \\
\text { Phrygian cadence. }\end{array}$ \\
\hline & & 3. Allegro, ${ }_{4}^{3}$ & $\begin{array}{l}\text { binary form with } \\
\text { introduction }\end{array}$ & \\
\hline \multirow[t]{3}{*}{ IV } & \multirow[t]{3}{*}{$\mathrm{F}$} & 1. Allegro, ${ }_{4}^{4}$ & ritornello form & \\
\hline & & 2. SICILIANA, Largo, ${ }_{8}^{6}$ & unitary form & $\begin{array}{l}\text { In } \mathrm{Bb} \text { major. Has brief } \\
\text { Adagio conclusion } \\
\text { leading to a Phrygian } \\
\text { cadence. }\end{array}$ \\
\hline & & 3. Vivace, ${ }_{4}^{4}$ & $\begin{array}{l}\text { binary form with } \\
\text { introduction }\end{array}$ & $\begin{array}{l}\text { In the style of a country } \\
\text { dance. }\end{array}$ \\
\hline
\end{tabular}


Table 2

(continued)

\begin{tabular}{|c|c|c|c|c|}
\hline \multirow[t]{4}{*}{ V } & \multirow[t]{4}{*}{$\mathrm{g}$} & 1. Andante, ${ }_{4}^{4}$ & binary form & $\begin{array}{l}\text { With appended } \\
\text { Phrygian cadence, } \\
\text { Adagio. }\end{array}$ \\
\hline & & 2. Allegro, ${ }_{4}^{4}$ & ritornello form & \\
\hline & & 3. Largo Andante, ${ }^{\frac{3}{4}}$ & & $\begin{array}{l}\text { In } \mathrm{Bb} \text { major. Two oboes } \\
\text { replace the organ in the } \\
\text { solo role. }\end{array}$ \\
\hline & & 4. Allegro, $\frac{3}{8}$ & $\begin{array}{l}\text { binary form with } \\
\text { introduction }\end{array}$ & \\
\hline \multirow[t]{5}{*}{ VI } & \multirow[t]{5}{*}{$\mathrm{c}$} & 1. Andante, $\frac{3}{2}$ & through-composed & $\begin{array}{l}\text { With appended } \\
\text { Phrygian cadence, } \\
\text { Adagio. }\end{array}$ \\
\hline & & 2. Allegro, ${ }_{4}^{4}$ & binary form & $\begin{array}{l}\text { With appended } \\
\text { Phrygian cadence, } \\
\text { Adagio. }\end{array}$ \\
\hline & & 3. Largo, $\frac{3}{4}$ & binary form & In Eb major. \\
\hline & & $\begin{array}{l}\text { 4a. MINUET I, Allegro } \\
\text { moderato, }{ }_{4}^{3}\end{array}$ & binary form & \\
\hline & & 4b. MINUET II & binary form & $\begin{array}{l}\text { In Eb major. Followed } \\
\text { by Minuet I da capo. }\end{array}$ \\
\hline
\end{tabular}

The second column gives the keys of the concertos - all different, as customary in sets written for instruments capable of playing easily in many different tonalities. ${ }^{53}$ The dominance of major keys (four works) over minor ones (two works) is typical for the period: very soon, major tonality would come to enjoy an even greater dominance - the greatest it has ever had in music's history. Interestingly, Concerto VI retains, for $\mathrm{C}$ minor, the two-flat key signature normal in the seventeenth century but gradually superseded by the modern form during the first few decades of the eighteenth. This suggests that Harry learned his craft from a teacher quite a lot older than him.

Column 3 lists the headings for each movement. In the four instances where this does not consist merely of a tempo marking we find a fashionable social dance (the Minuet), a fashionable theatrical dance (the Siciliana), a traditional but in England surprisingly durable dance (the Giga, or Jig) and a fugue. The latter is not, however, a traditional fugue with approximate parity of the parts but a concertante fugue in which the episodes alternating with expositions of the subject and countersubjects make only fragmentary or indirect reference to the material treated in counterpoint, offering instead exactly the same type of display writing and accompaniment to it employed in the solo episodes of concertos. ${ }^{54}$

${ }^{53}$ Following convention, major keys are shown in capitals, minor ones in lower case.

${ }^{54}$ On concertante fugues, see Talbot, Vivaldi and Fugue, 82-83 and elsewhere. Young composers 
The number of movements (ignoring tailpieces in slower tempo tacked on to the end of movements as transitions to a following movement, which are shown in column 5) varies between three and four. All the concertos, however, have a three-movement "core" in a fast-slow-fast configuration. Concertos I, III and IV provide no more than this; Concerto II interjects its lively fugue before the final movement; Concerto V opens with a concise, intrada-like slow movement not unlike some of Corelli's preludes in his chamber sonatas; Concerto VI not only features a slow opening movement of a different type but also casts its last movement in the composite form of a pair of minuets (the second contrasting with the first by being scored for keyboard alone), with a reprise of the first minuet to close the work.

Turning to column 4: as we saw earlier, ritornello-form movements, all of which dominate their respective work in weight and duration, occur as first allegro movement (always in common time) in Concertos I-V. Not always far behind in complexity and length are the five mostly fast movements described as "binary form with introduction". Here, the introduction is an orchestral prelude preceding the forward-facing repeat sign that marks the start of the binary structure proper. This variant of binary form with an independent introduction is imported directly from the repertoire of English song of the period, where it constitutes one of the favourite structural types. To my knowledge, only one other composer of concertos, William Hayes (1708-1777), sometimes employs a similar layout - as in Harry's case, only in final movements. ${ }^{55}$ Chronological priority is hard to determine for certain, but Harry seems more likely to have been the originator. To illustrate the relationship to vocal music, the opening of Harry's song "Rouse, Britons, Drive the foe" (mentioned earlier) and that of the third movement of Concerto IV are juxtaposed as Music examples 1a and 1b. ${ }^{56}$

often included one or more fugues in their first opus to give evidence of their good technical foundation.

${ }^{55}$ Hayes adopts a similar form for the minuet finale of a keyboard concerto in D major - (W)6:011, dating from 1755 and published complete in English Keyboard Concertos, 29-46 - as well as for the finales of concertos in $\mathrm{G}$ and A major (ibid., XXVIII), the first of which certainly dates from the period of Burgess's concertos. My thanks to Peter Lynan for drawing my attention to Hayes and providing extra information on these works. It is interesting and perhaps significant that an earlier version of the finale of (W)6:011 - used in a different concerto, (W)6:001, which may well date from before 1740 - does not have any introduction. I owe this detail to Simon Heighes (in private correspondence). The above concertos are catalogued in Heighes, Lives and Works, 343,345 .

${ }^{56}$ Unless otherwise stated, the organ (or harpsichord) part is not notated separately in the music examples for tutti passages where it merely doubles instruments of the orchestra. 
Music example 1a

Henry Burgess, Junior, opening of the song "Rouse, Britons, Drive the foe" (1746)
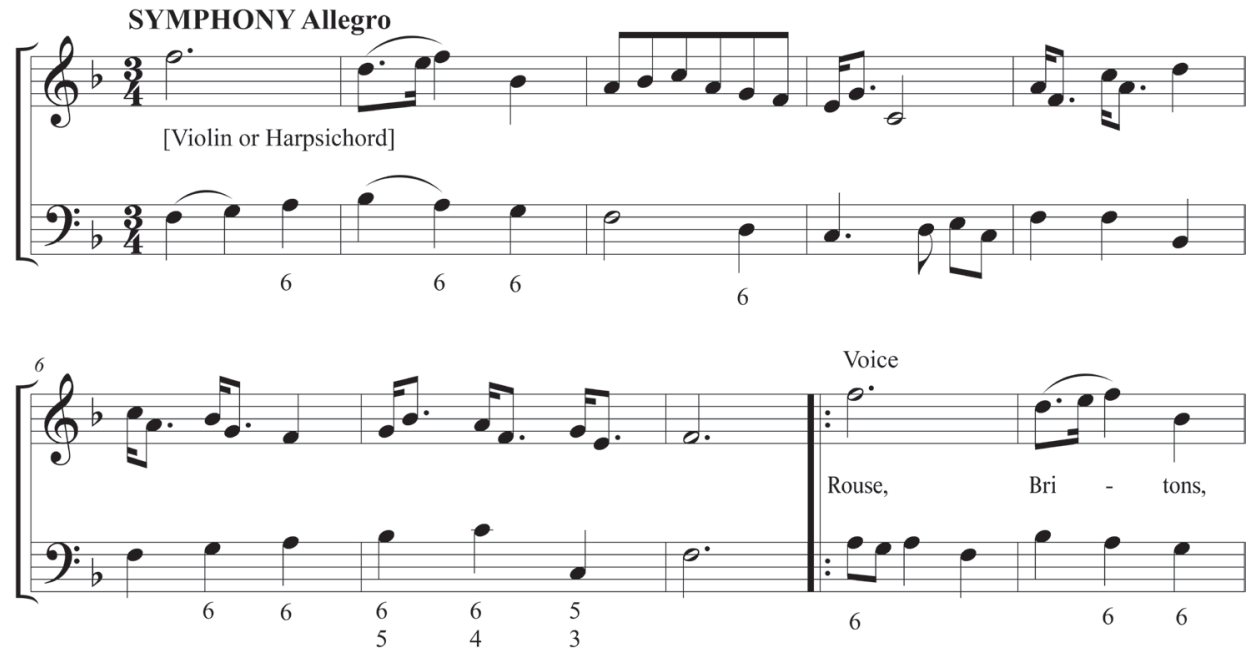

Music example 1b

Henry Burgess, Junior, opening of the third movement (Vivace) of Concerto IV
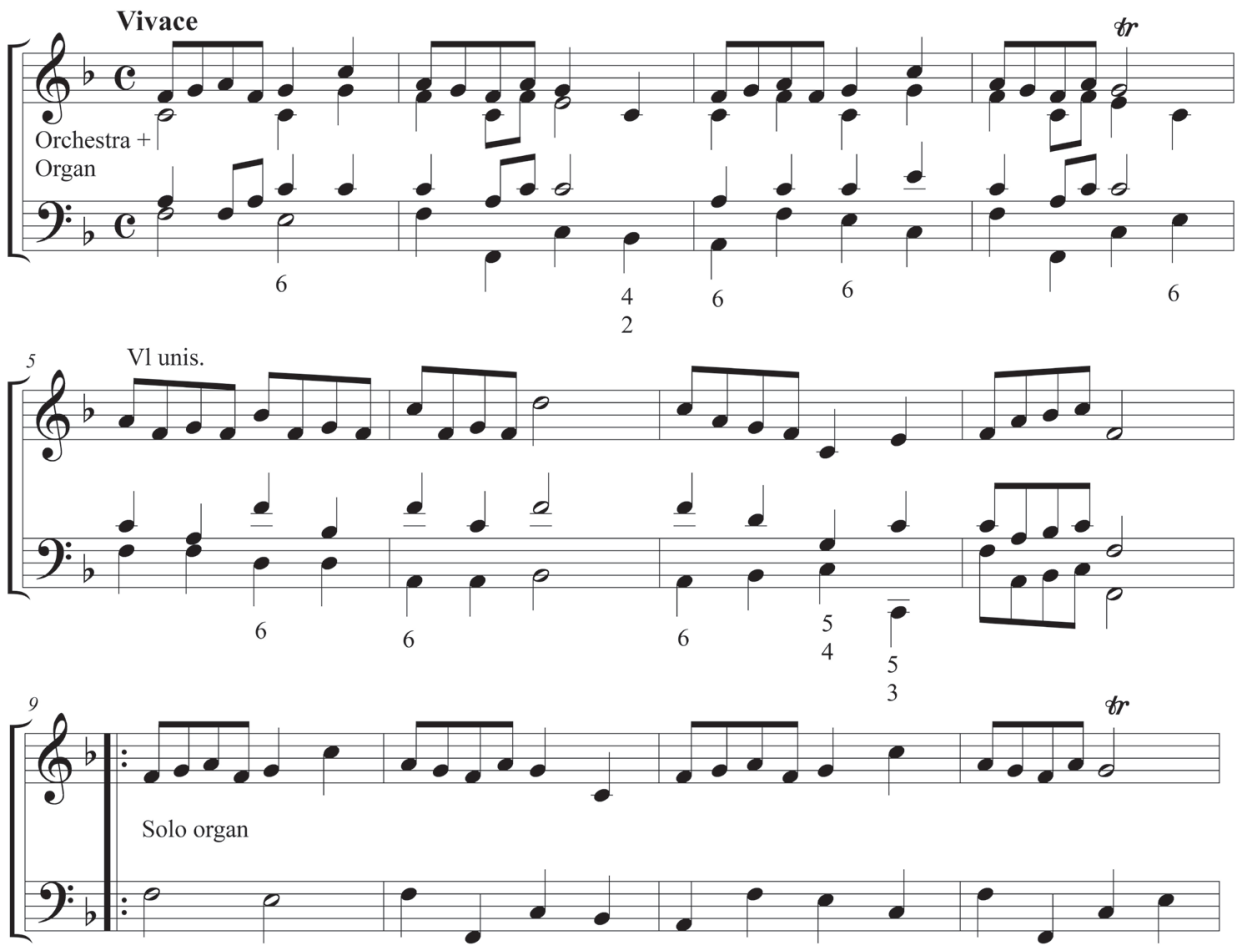
Though not so labelled, the concerto movement, which despite its common time signature functions as if in cut time (alla breve) metre, has the lineaments of the popular type of English dance known as the country dance, which one might describe as the indigenous counterpart of the French gavotte. Its faux-naïf charm recalls Handel's wellknown "Harmonious Blacksmith" air from his keyboard suite in E major (HWV 430) and similar movements in the symphonies of William Boyce.

The binary-form movements without a separate introduction, which are all in slow tempo, are unusual for their period in making surprisingly little use of thematic rounding, meaning a reprise in the tonic of the opening theme (or at least its first notes) during the second section. Although he can be facile in other ways, Harry does not readily "paste in" blocks of music mechanically. Whenever he repeats, he is apt to vary. Revealingly, when organ and orchestra share phrases in dialogue or simultaneously, very often one or the other introduces unanticipated elaborations or, indeed, simplifications as if to tease its partner (this is a recognizably Handelian feature).

This leaves the few movements that I term "unitary" or "through-composed". The difference between the two descriptions is that the first is distinguished from binary form only by having no sectional repeats and no prominent caesura at the point where the alternate key (dominant or relative major) is confirmed with a cadence, whereas the second unfolds freely, often in "consciousness-stream" fashion. This is the case with the opening Andante of Concerto VI, where the strict patterning of rhythm and articulation is offset by the exploratory, calculatedly unpredictable nature of the harmony and modulation (Music example 2). This manner is in fact very old in concertos, pre-Vivaldian in fact (similar movements occur in Torelli and Albinoni). It seems, like the fugue, to be a nod towards the "ancient" style, which had many devotees in England throughout the century.

\section{Music example 2}

Henry Burgess, Junior, opening of the first movement (Andante) of Concerto VI
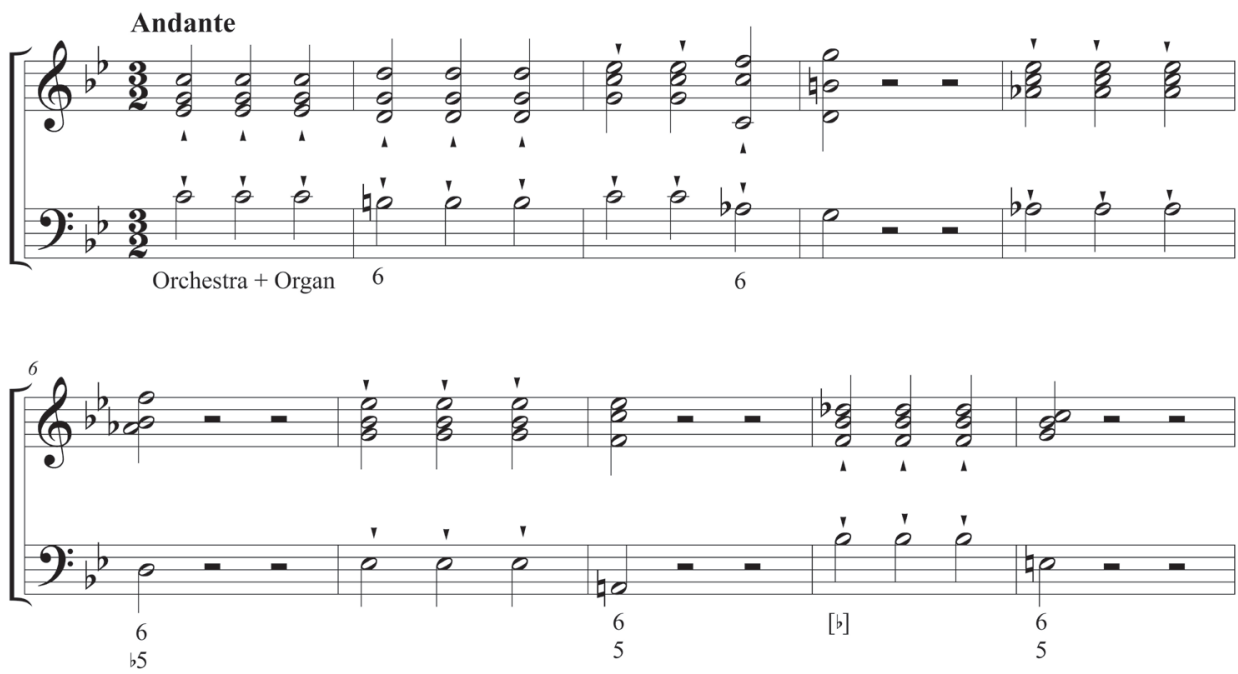


\section{Music example 2}

(continued)

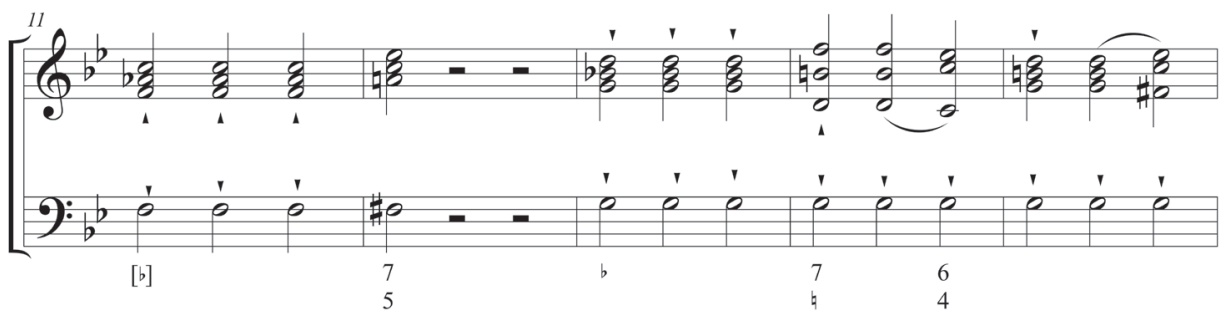

From column 5 we see that Harry is extraordinarily fond of ending his tailpieces to movements with a Phrygian cadence, a typically Corellian gesture. Fortunately, he is quite inventive in varying the inner-part details of such cadences.

The same column identifies the key of the slow movement within the three-movement "core" group mentioned earlier. Generally, this is the relative major or minor, as it would be in Handel or J. S. Bach, but Concerto IV is progressive in using instead the subdominant, statistically the most common choice in early Classical instrumental works.

\section{The Ritornello-Form Movements}

Not all the orchestral passages in the ritornello-form movements are describable as ritornellos. This term is best reserved for the structural pillars that in Harry's case (as in the earliest concerto tradition represented by Torelli and Albinoni, but not always in Vivaldi) are characterized by use of an invariable head-motive, whose continuation in interior statements is liable to mutate into something simpler and shorter than in the original statement, and which is nearly always a closed period starting and finishing in the same key. ${ }^{57}$ Other, shorter orchestral passages are embedded within the solo episodes separating ritornello statements. These are generally very loosely related motivically to the ritornellos or, as an alternative, reproduce or paraphrase the solo material itself, as in echoes and call-and-response passages, for which the model is clearly Handel (see later discussion). Like Vivaldi, Burgess writes segmented ritornellos consisting of juxtaposed discrete phrases, some of which are repeated at the same pitch or in sequences. Perhaps the most memorable (and Vivaldi-evoking) of the opening ritornellos is that of the second movement of Concerto $\mathrm{V}$, as jaunty as a hornpipe and with a central modulation to the relative major that anticipates the later tonal trajectory of the movement (Music example 3). This example concludes with the opening bar of the first solo episode to illustrate how it is Harry's custom to launch his solo display with a paraphrase of the start of the preceding ritornello. This is a Vivaldian practice, but unlike Vivaldi himself, Harry never recapitulates the same paraphrase towards the end of the movement. In a way, the first solo's opening is morphologically more akin to the start, following a thematically related introductory "symphony", of the main, texted portion of a typical English song of the period.

${ }^{57}$ Exceptionally, the opening movement in Concerto III "fuses" the second and third ritornellos to create a single unit modulating from $\mathrm{E}$ major to $\mathrm{F}$ sharp minor. This form of telescoping is very common in Vivaldi. 
Music example 3

Henry Burgess, Junior, opening of the second movement of Concerto V (bass figures omitted)
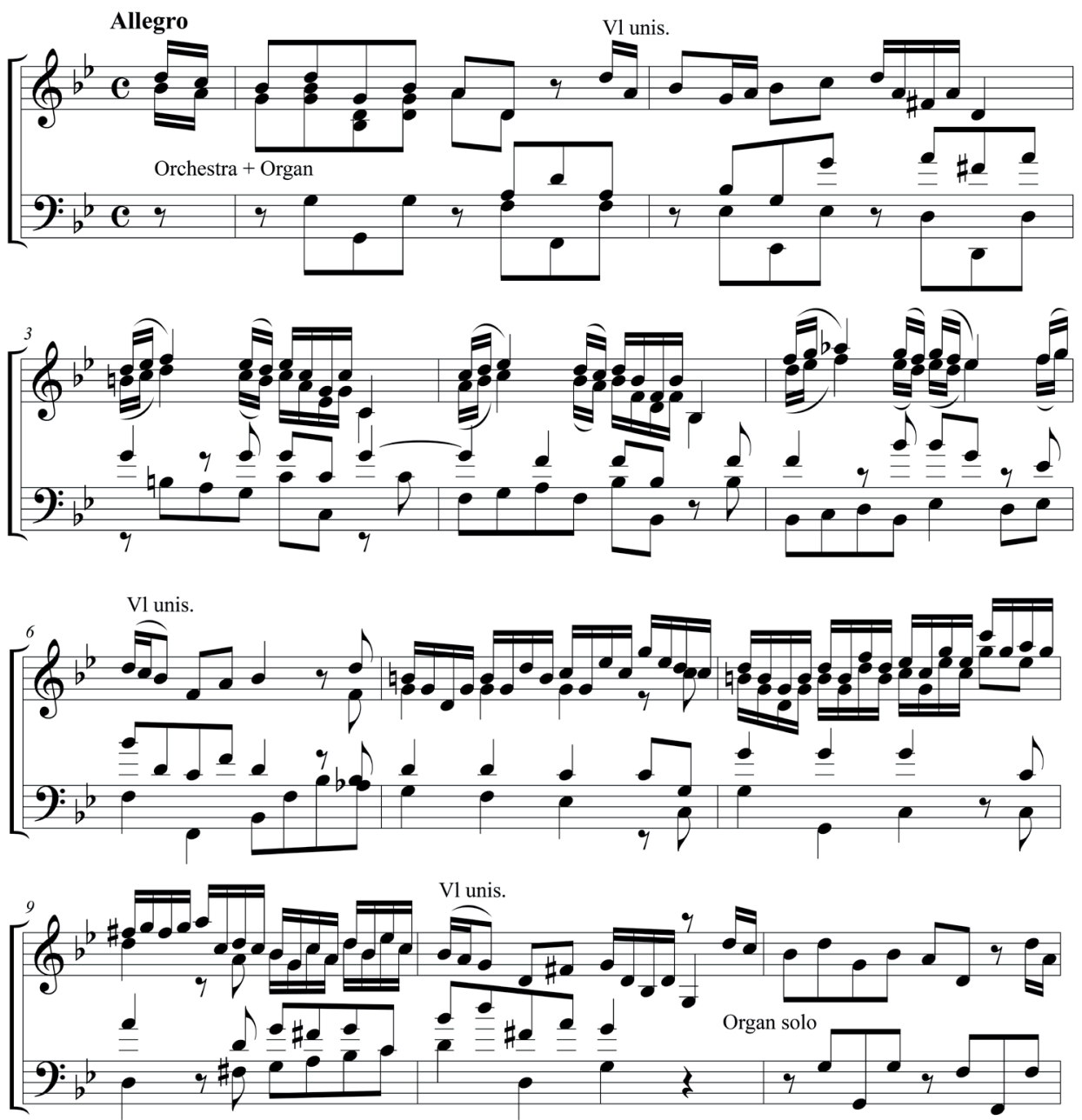

Ritornellos afford Harry an opportunity to demonstrate his command of orchestral texture, which embraces the full range from stark unison passages to complex multistranded ones. The most striking ritornello statement in the whole set (quoted as Music example 4) is the second, in D minor, from the same concerto, which terminates with something approaching the rhetorical weight and venom of the first bars of Handel's Dixit Dominus (HVW 232). 


\section{Music example 4}

Henry Burgess, Junior, bars 23-29 of the second movement of Concerto V
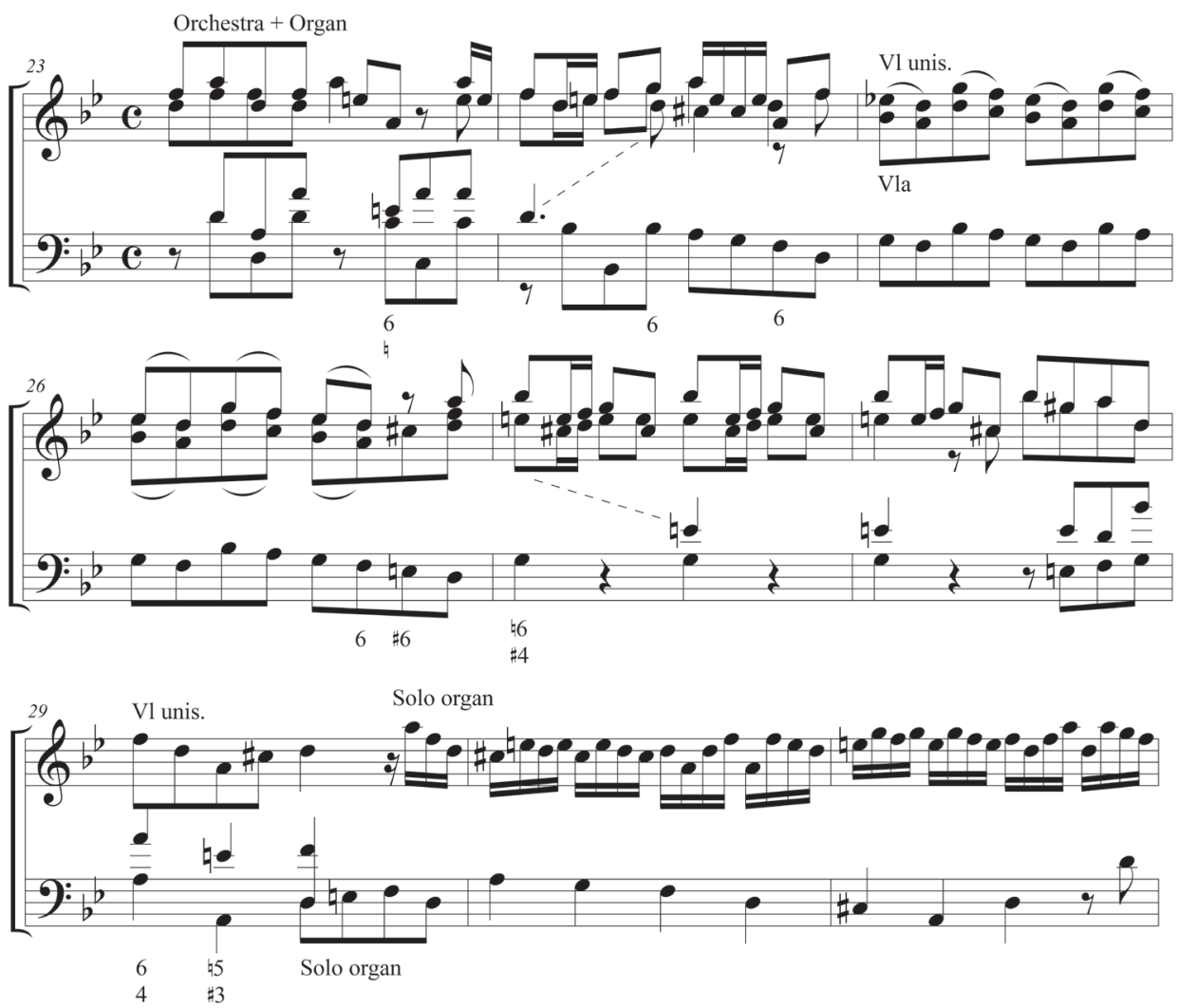

The spirit and technique displayed in these movements also permeate Harry's quick movements cast in other forms. The fugue in Concerto II can be viewed as a variant of ritornello form in which the solo episodes remain as before, but conventional ritornellos are replaced by fugal expositions unified by using a common subject, though differing in length, configuration and tonality. ${ }^{58}$ As regards the binary-form movements with orchestral introductions, the standard procedure is to begin both of the repeated sections with a long solo for the organ and end both with a short tutti referring back, either loosely or more strictly, to the material of the introduction.

\section{The Solo EpIsodes}

Except for the sporadic interjections by the full orchestra already discussed, Harry's solo episodes are scored quite literally for the solo instrument alone: in the quick movements there are no counterpointing melodies or figures on selected instruments wafting in and

${ }^{58}$ I use 'exposition' here in its American meaning referring to a block of entries at any point in the movement rather than in its traditional British meaning, which refers only to the initial block. 
out during the episodes, as would most likely be the case in an organ concerto by Handel or Felton or even a solo concerto by Vivaldi. Harry sets a premium on transparency and a rather formulaic tidiness. Part of the reason is doubtless a wish not to complicate matters for the alternative mode of performance without organ.

At first sight, these episodes appear to consist of little more than extended series of semiquavers in the right hand, lightly supported with longer notes in the right hand, and full of mechanical repetition of all kinds. Closer acquaintance reveals greater subtlety, however. The structure of the figures changes periodically in time to avert tedium; the transitions from one figure to the next are smooth and often underpinned by a semiconcealed element of continuity such as the persistence of a tiny cell; most important, convincing cycles of tension and release are created. For this last purpose, the role of the left hand is crucial. Its well-calculated fluctuations of speed, and between even and uneven rhythms, regulate, so to speak, the music's temperature and make an independent claim on the listener's attention. At climactic moments the bass often joins the treble in semiquaver motion, predominantly in the parallel tenths so beloved of Handel. It may be noted here that a pervasive feature of Harry's writing, one seen at its clearest in the solo episodes of his concertos, is what Eleanor Selfridge-Field, writing about Albinoni, aptly called "emphatic consonance": a bias towards the euphony of thirds, sixths and their compound equivalents, unsullied by the asperities introduced by suspensions. ${ }^{59}$ In keeping with this bias, the chains of interlocking seventh chords so dear to Vivaldi are absent, and the dominant triad at cadences often dispenses with a $5 / 4$ or $6 / 4$ prefix.

Another important regulator is the varying degree of tonal stability. At times, the music is kept in a swirling tonal flux, with short-lived and occasionally rather unexpected tonicizations of a great variety of scale-degrees, but these are counterbalanced by moments of exultant tonal and harmonic stasis celebrating arrival at, or departure from, a staging post on the music's itinerary. No one passage can illustrate all the points made above, but the first part of the third solo episode in Concerto I (leading up to an orchestral interjection), shown in Music example 5, gives a flavour. The poignant dominant minor ninth in bar 72 is one of the most exquisite harmonic touches anywhere in the concertos.

${ }^{59}$ Selfridge-Field, Venetian Instrumental Music, 200. 
Music example 5

Henry Burgess, Junior, bars 58-73 of the first movement of Concerto I
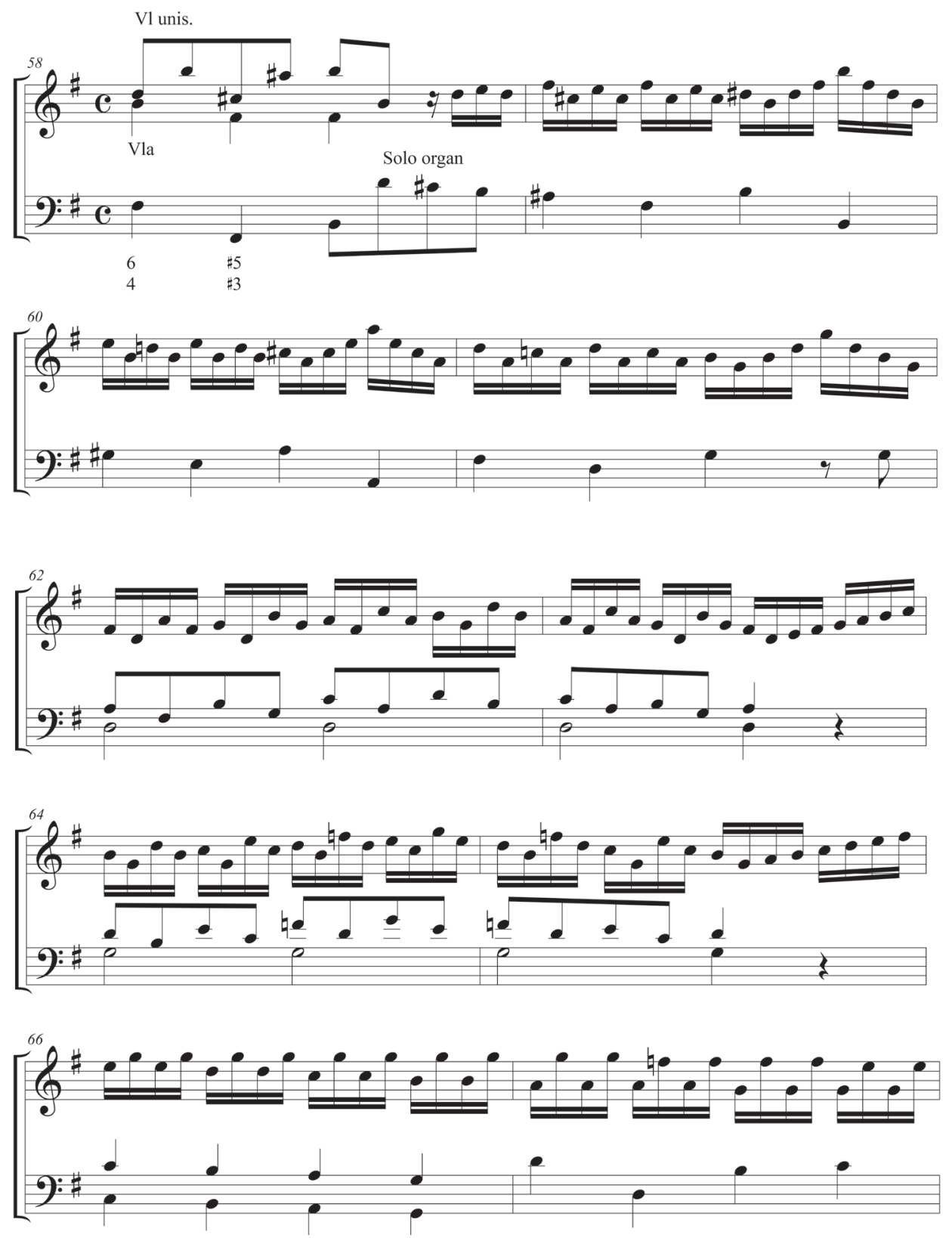

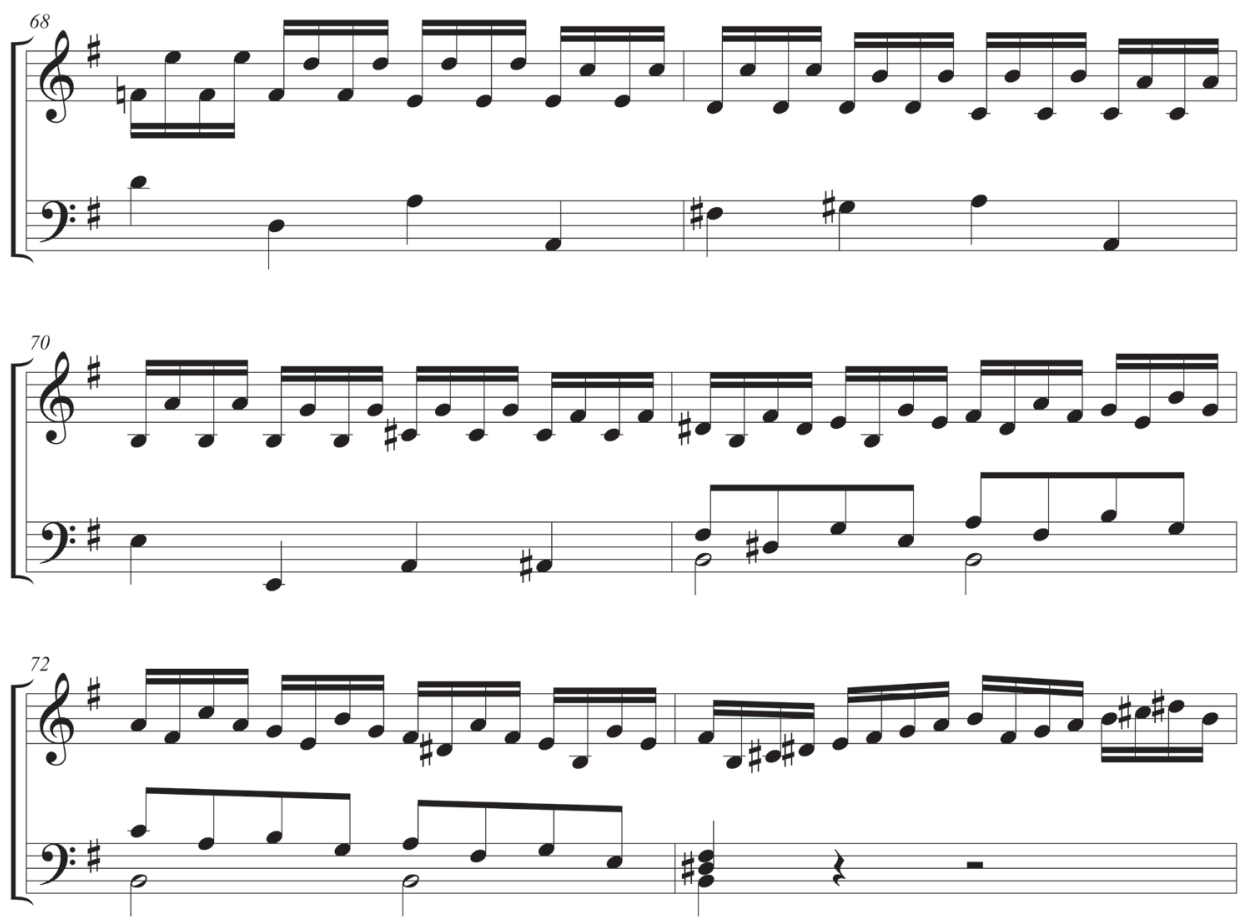

Here and there, the stream of right-hand semiquavers may be delightfully disrupted by a triplet group or by flurries of demisemiquavers (Music example 6). Harry understands well that the less often an effect is encountered, the more impact it makes when it does appear. He also has the useful knack of creating figures that "lie under the fingers" in a satisfying way so that the sound often becomes more brilliant than the technical ability needed to achieve it. In the background is always a solicitous consideration for amateur players. That is the reason why, unlike Handel, Harry leaves only the narrowest sliver of space for free improvisation by the soloist - merely an "organo ad libitum" direction (inviting performance of a short cadenza) at the final perfect cadence of the Largo of Concerto III. 


\section{Music example 6}

Henry Burgess, Junior, bars 17-20 of the second movement of Concerto V
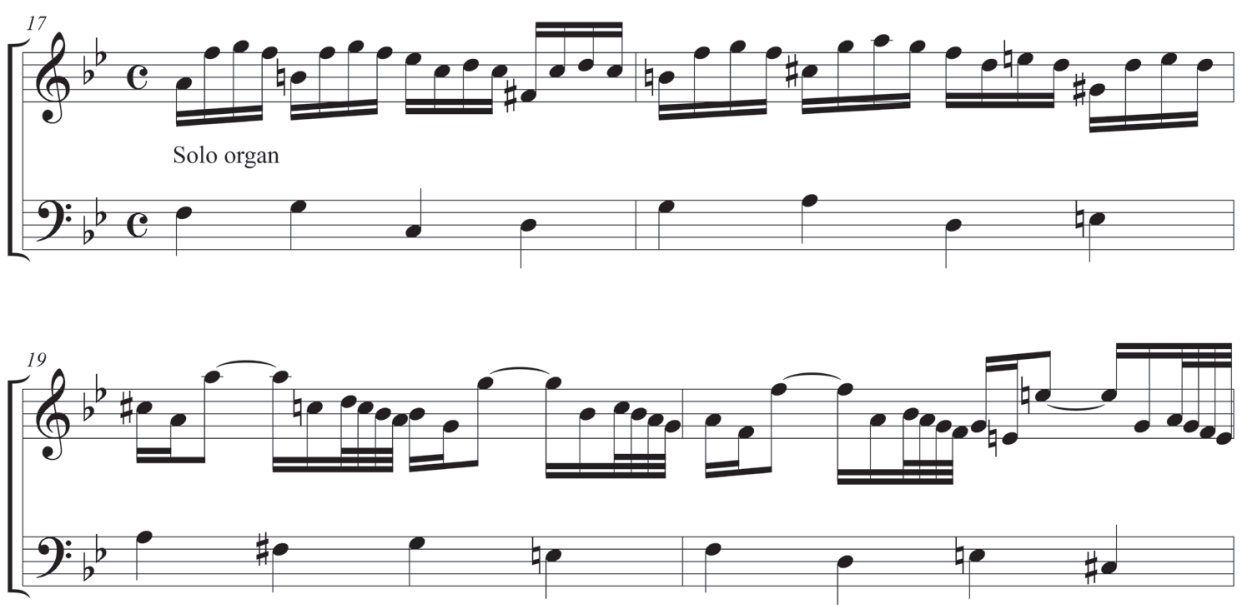

Discussion of the solo episodes would be incomplete without illustration of the short call-and-response passages that pepper these sections. Music example 7 comes from Concerto II. The small variations - leaving aside the harmonic content - between call (organ) and response (orchestra) clearly arise from a wish to counterpose the liveliness of the first to the stateliness of the second, and perhaps also to pique the listener's ear.

\section{Music example 7}

Henry Burgess, Junior, bars 42-49 of the first movement of Concerto II
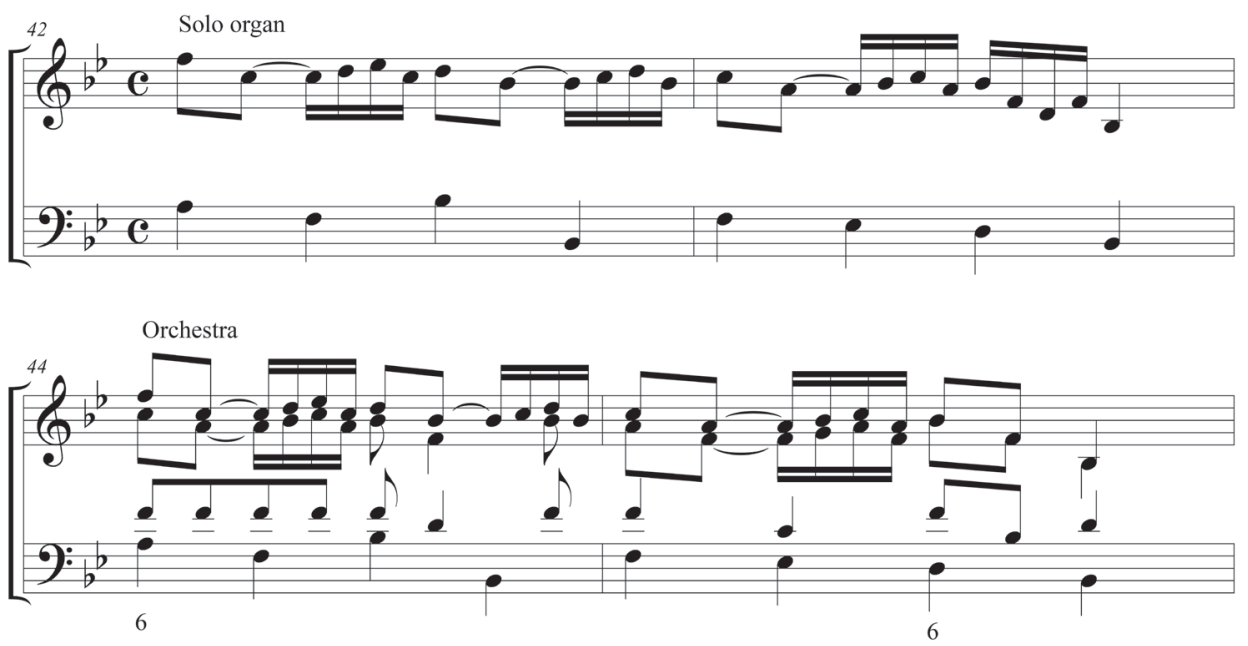

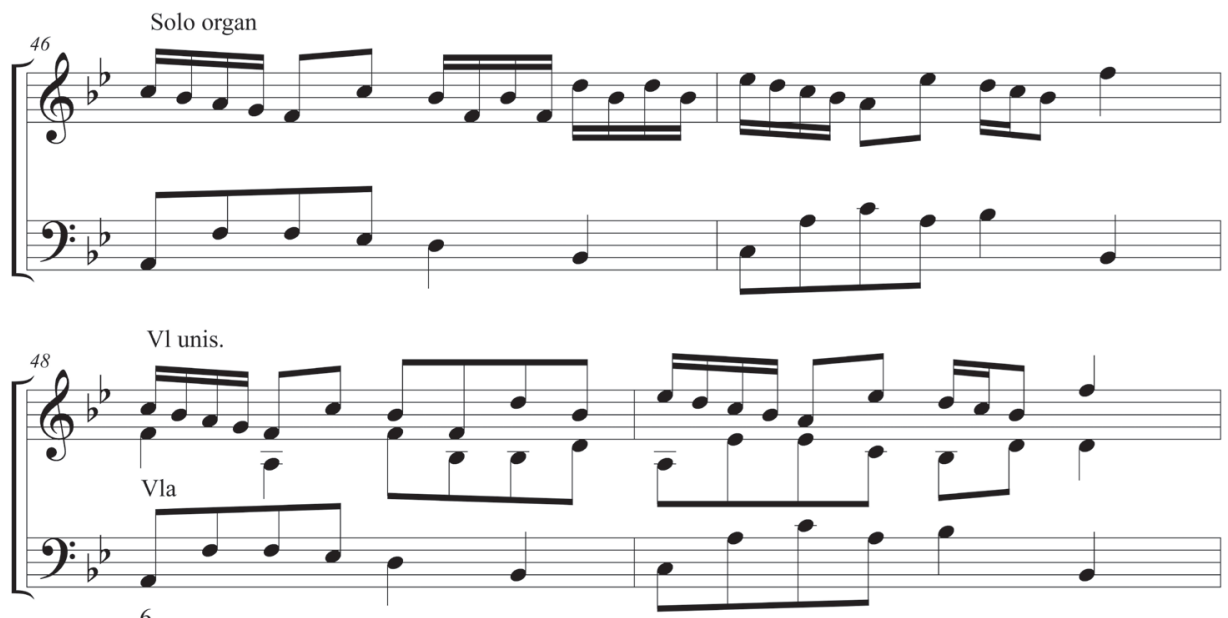

The SLOW Movements

The great variety of style and form in Harry's slow movements offsets the uniformity of the fast ones. He observes the normal distinction between opening slow movements (present in Concertos V and VI), which have a dignified, intrada-like character already signalled by the choice of common time, and internal slow movements, which form the emotional core of the work and are always in triple or compound metre. All the latter are short, some extremely so. The scoring varies: Concertos I and II employ orchestral texture throughout, while Concertos III-VI alternate tutti and solo sections (the second minuet in Concerto VI is scored for unaccompanied organ). Three of the movements (in Concertos I, II and IV) feature inverted dotting (the so-called Scotch Snap, a favourite ingredient of English - and of course Scottish - music already long before alla zoppa or Lombardic rhythm became the rage in Italy), which we encountered earlier in Music example 1a. This mannerism, cultivated particularly in songs, reached a peak of popularity in Britain in the central decades of the eighteenth century. We find it even in sicilianas written there, in contrast to the Italian tradition, as Music example 8 demonstrates.

\section{Music example 8}

Henry Burgess, Junior, opening of the second movement of Concerto IV

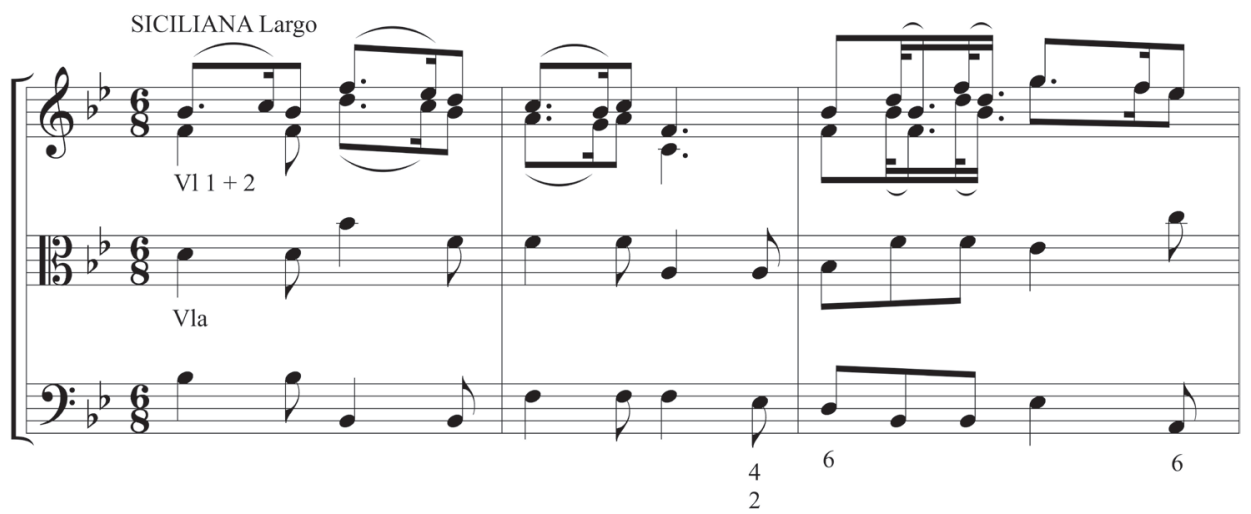


Music example 8

(continued)

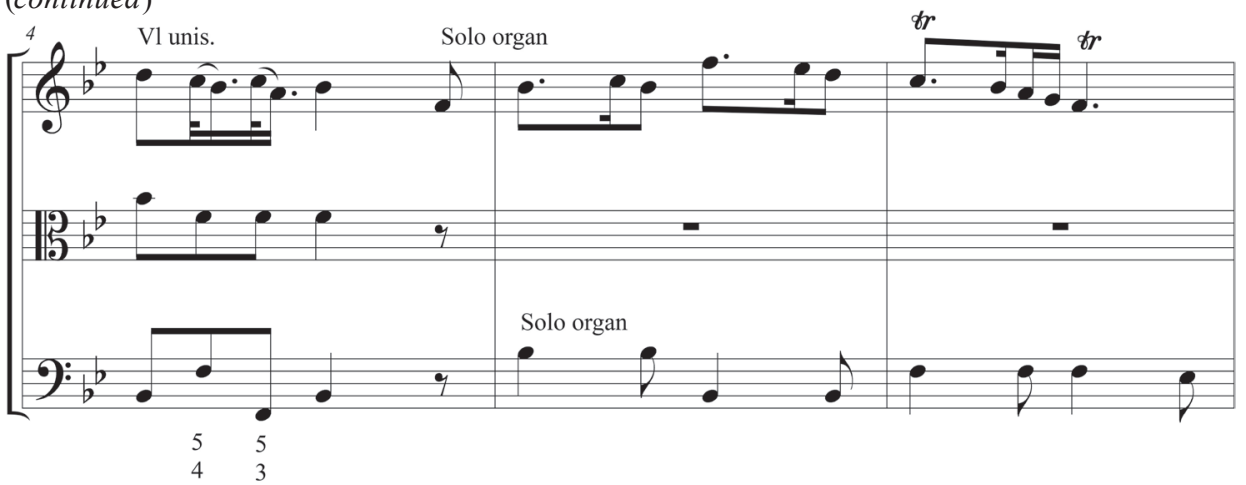

To illustrate Harry's lyrical gift, we need go no further than the second movement of Concerto I, quoted in its entirety as Music Example 9. Note the slightly unexpected turn to the subdominant in bars 5-8: a liking for a momentary dip into the subdominant area is noticeable throughout Harry's concertos. Not literally "modal" but similar in effect, this feature can impart, as here, a pleasing mellowness. The ornament sign (added to the keyboard part alone) in bar 13, which, ironically, becomes relevant only when this explicitly "senza organo" movement is played on the keyboard without orchestral accompaniment, denotes not an ordinary mordent but its peculiarly English variant known as a "beat" ${ }^{60}$ This prefaces a pincé with its lower note in the manner of a rising appoggiatura. A moment to relish is the sudden descent of the viola to its lowest register for the final Phrygian cadence, which produces an attractively cavernous sonority.

\section{Music example 9}

Henry Burgess, Junior, the second movement of Concerto I
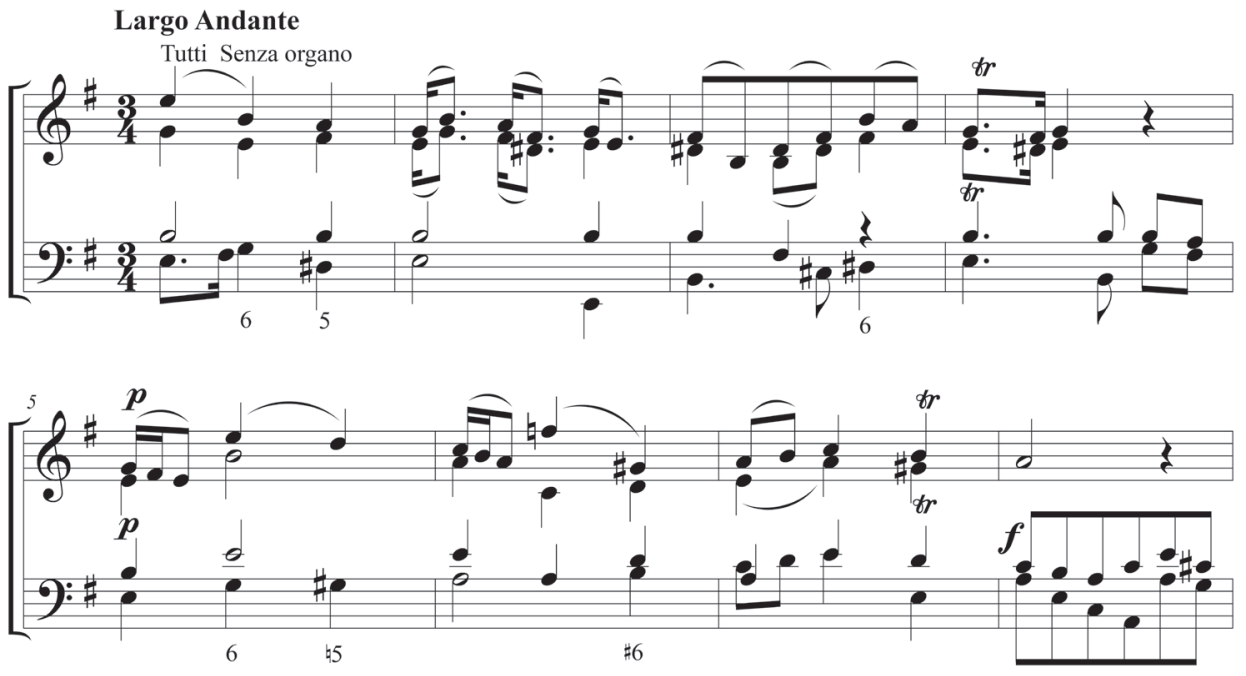

${ }^{60}$ On the history, nature and usage of the beat, see Johnstone, "English Beat". 

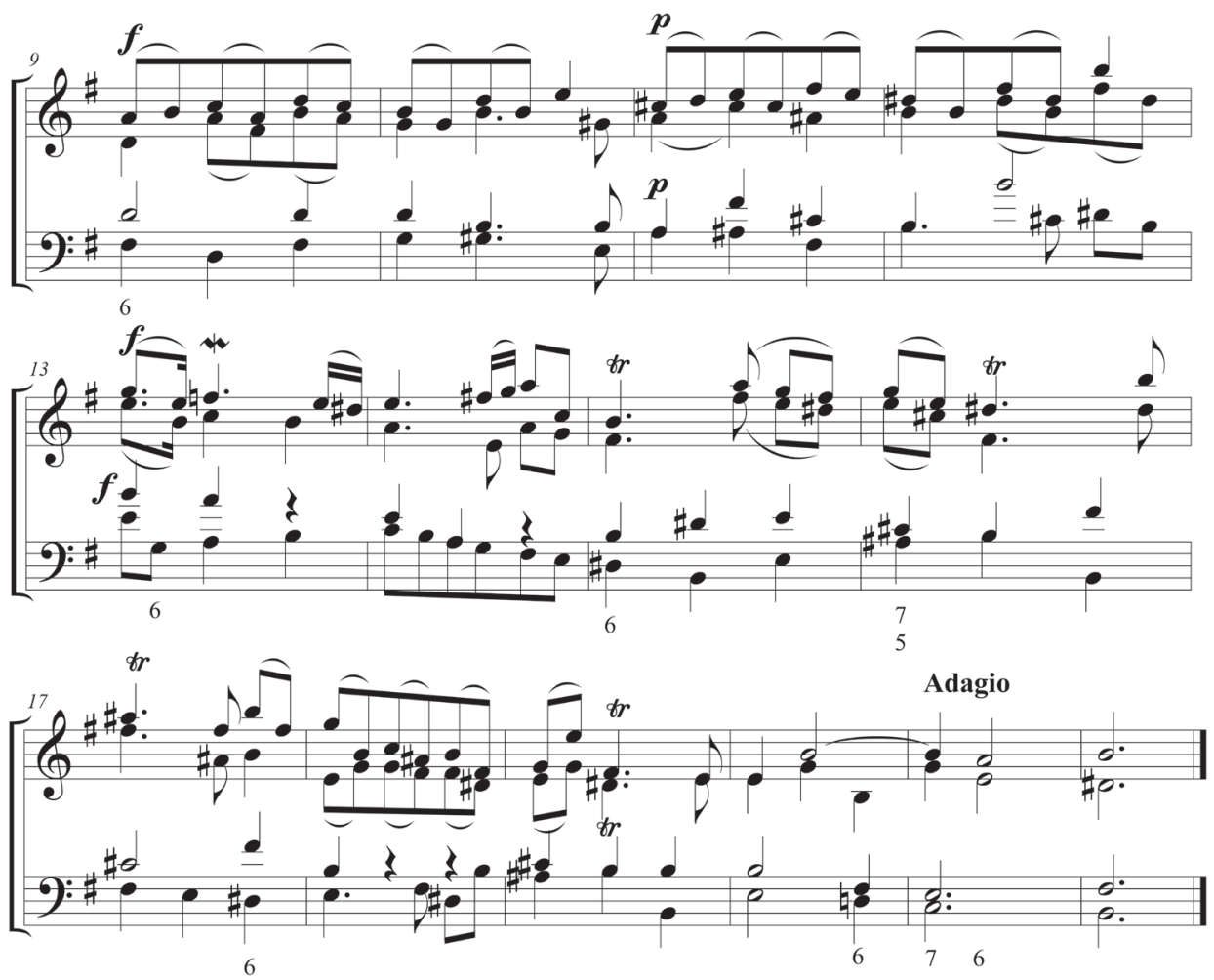

InSTRUMENTATION AND ORCHESTRATION

The specified accompaniment for Harry's concertos consists of the usual four-part strings (with tacit expectation of the doubling of the cello in the lower octave by contrabass) plus continuo. These become augmented in Concerto $\mathrm{V}$ by a pair of obbligato oboes that replace harpsichord in the solo role in the third movement. The idea of using an "alternate" soloist in the internal slow movement was not new: Vivaldi, for instance, substitutes a solo cello for a pair of horns in the central movement of the concerto RV 538 and a pair of recorders for a pair of oboes in that of the concerto RV 566. But Johnstone and McGuinness, and later Lynan, are absolutely right to draw special attention to the use of the oboes. ${ }^{61} \mathrm{Handel}$, too, uses oboes in organ concertos - but only in an optional, reinforcing role. The question arises whether Concerto V, or even all six concertos, should add oboes to the ripieno. The answer seems positive in the case of Concerto $\mathrm{V}$, since if one needs instruments for one movement, it would be uncharacteristic of early eighteenth-century practice to omit them from the others when they have the opportunity to fill a conventional role there. Moreover, the compass for the violins in that concerto lies relatively high, and there are very few places where a Baroque oboe in $\mathrm{C}$ doubling one of the violin parts needs to

61 Johnstone and McGuinness, "Concert Life in England I", 65; Lynan, "English Keyboard Concerto", 85. 
adjust its part through upward transpositions or brief omissions, something usually carried out at sight by practised players. For the other concertos, the case is less clear-cut, but it would certainly be idiomatic to include oboes (and perhaps bassoon on the bass) in performances with numerous players.

Concerto $\mathrm{V}$ also has a separate ripieno bass part for the third movement, where the Basso part is temporarily renamed "Violoncello". The idea here is that the violoncello and its keyboard continuo partner accompany the oboes in solo passages, while the "Basso ripiano" (Harry renders the bisyllable "pieno" a second time incorrectly as "piano" in his direction "organo piano" at the head of Concerto VI!) joins in whenever the violins and viola are active. This movement contains more complex and intricate textures than any other in the set, and one may well wonder whether Concerto V was not the very work labelled "grand" in the puff for the concerto's performance at Cuper's Gardens in June 1741. Its second repeated section (Music example 10) illustrates the point.

\section{Music example 10}

Henry Burgess, Junior, the second repeated section of the third movement of Concerto $\mathrm{V}$
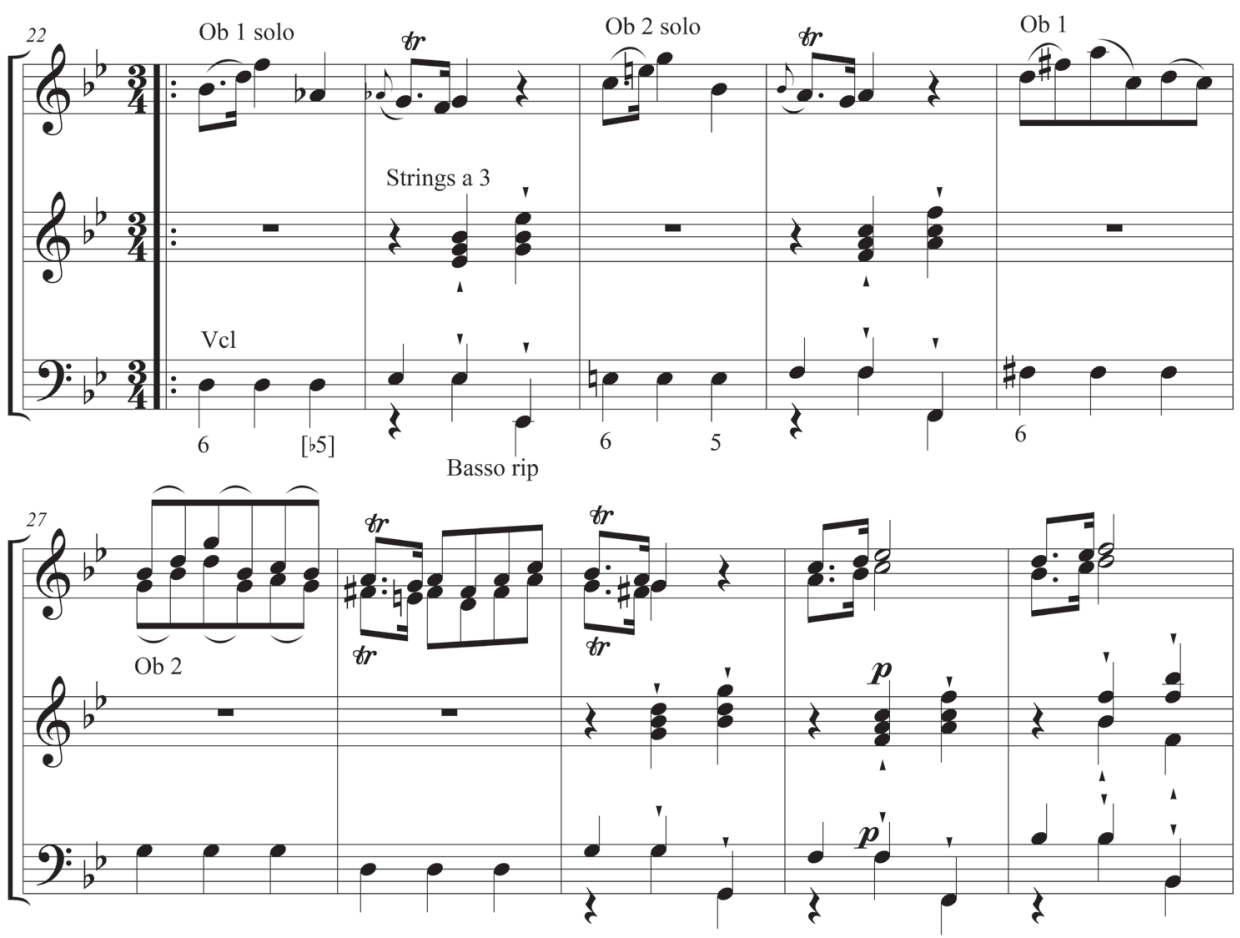


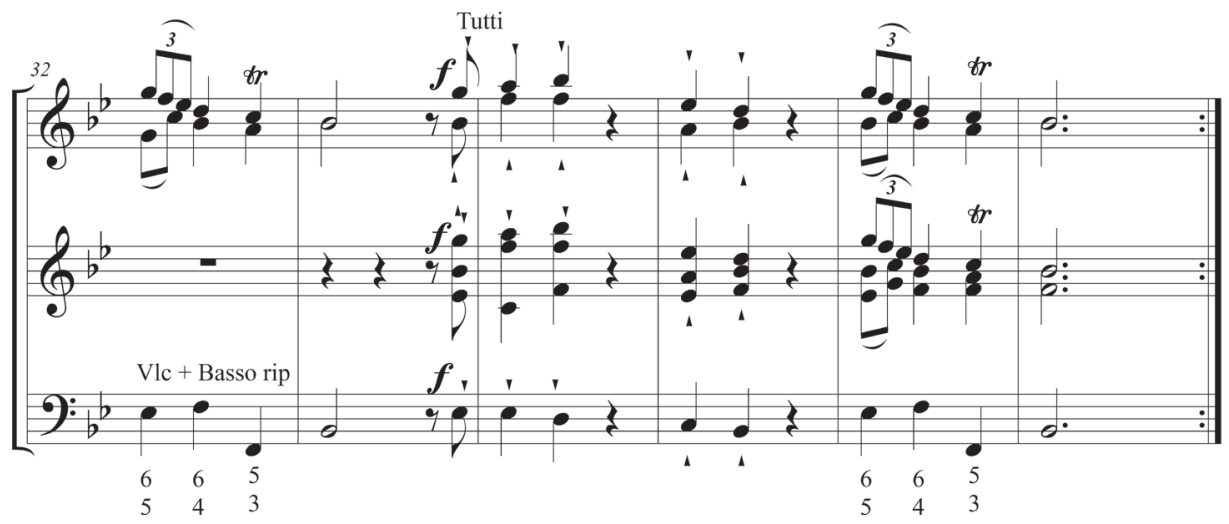

As noted earlier, Harry usually operates with much thinner textures. But he orchestrates in a forward-looking way, common in English theatre music of the mid-eighteenth century, which one might describe as "free-voiced". The essence of this technique is that contrapuntal lines bifurcate (one line branches into two) or reunite (two lines merge into one) with absolute freedom, often within the course of a single phrase. This flexible approach contrasts with the more traditional, schematic one still being adopted by Handel (plus Felton and other English composers in the genre), where two parts are either independent all the time (at least, for the duration of a phrase) or double one another strictly. Such extra room for manoeuvre enables Harry to achieve subtle transitions between light and shade or between robustness and gracefulness. It also brings fresh possibilities to the part-writing, facilitating some inventive writing in the inner parts. Take, as a simple demonstration, bars 5-8 of the Largo in Concerto VI (Music example 11). Here, the upper string parts begin in sonorous three-strand harmony. They then reduce, by merging, to two strands, and finally to only one, creating a smooth "taper" effect. The musical lines themselves continue seamlessly even if the instruments playing them change (as happens when the viola takes over from the second violin in the penultimate bar). Similar freevoiced treatment can be seen in several earlier music examples in this article.

\section{Music example 11}

Henry Burgess, Junior, close of the first section of the third movement of Concerto VI

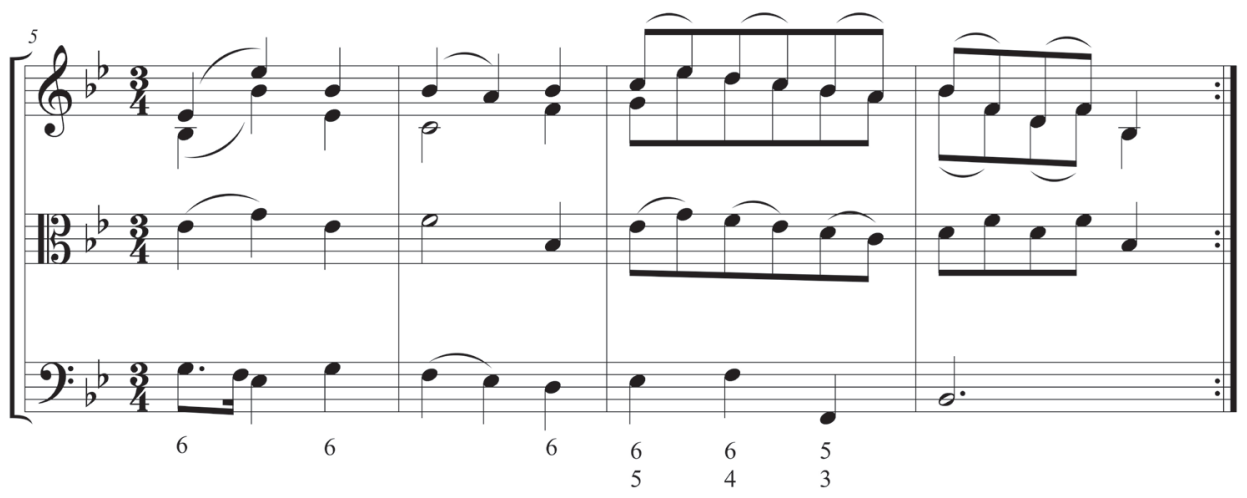




\section{Conclusion}

While no one should elevate Henry Burgess, Junior, to the ranks of the great or even the middle-ranking masters, from which he is immediately debarred in any case by the small size of his output, he is certainly not the negligible figure suggested by the paucity of earlier interest in his work and life. He deserves credit for being the first English-born musician to compose and publish a full set of free-standing keyboard concertos (with acknowledgement, however, of Avison's earlier lone example), and also for being the first composer anywhere to use oboes as co-soloists in a keyboard concerto. Most of all, he should be admired for his enterprising and original synthesis of elements drawn from Handel, the Vivaldian tradition and - so unexpectedly - English song. These achievements make his music interesting, but they do not, by themselves, make it good. I would argue, however, that Harry's concertos easily pass the threshold separating the merely noteworthy from the worth performing. They are instantly attractive, bubbling with vitality, varied enough to avoid predictability and supremely practical, being performable by the solo keyboard instrument (a) with orchestra and continuo harpsichordist, (b) with orchestra but no continuo harpsichordist (since the soloist, if playing from a full score, can easily take over the realization of the continuo during tutti sections, where he or she is always either silent or merely doubling string parts) or (c) without accompaniment. I regard it as no disparagement to suggest that they are ideal music for a school or college orchestra or a local music society as a first step towards more testing fare, such as the Handel organ concertos or the Bach harpsichord concertos.

The biographical account I have been able to give of Harry and his father is rather thin, to say the least, but it at least supplies the bare bones that future scholars will, I hope, be able to flesh out. Composers do not usually strive to make their lives more incidentpacked in order to gratify the wishes of their biographers, and if both Burgesses led a quiet life remote from the limelight (except for Harry's few golden years as soloist in his own concertos), they may have felt perfectly comfortable and fulfilled doing so. But there are a few interesting things we can learn from their lives, and especially their publications, about the wider English scene. The father's keyboard "lessons", not discussed beyond a simple listing in the authoritative history of English keyboard music by John Caldwell, ${ }^{62}$ offer an insight into the humble sphere of "familiar" music, which was so closely connected with the world of private music teaching. The son's cantatas, though lacking the originality of his concertos, exemplify well the deviant nature of the English variety of cantata, which unlike its Italian prototype came eventually to take its poetic texts not from purpose-written verse (poesia per musica) already neatly divided into recitative and aria stanzas, but from poetry of any type, often not intended originally for music, which it was the composer's responsibility to select and divide into aria and recitative sections at his own pleasure. As for Harry's late trio sonatas, once it again becomes possible to study them, we will find out whether or not new wine was poured into old bottles.

One unanswered question continues to obsess me. Was the epithet "little" applied by Burney to Harry a synonym for "Junior", an expression of disparagement de haut

${ }^{62}$ Caldwell, English Keyboard Music. 
en bas or a reference to actual short stature - either at the point when the latter had just reached maturity (c. 1738) and made his début as a composer or perhaps earlier, during his teenage years? Could Harry have been a child prodigy on the harpsichord? A painting or drawing of him that could resolve the matter is something eagerly to watch out for. 


\section{Bibliography}

\section{OnLINe Resources}

Ancestry Library Edition. "England \& Wales, Prerogative Court of Canterbury Wills, 1384-1858”. Accessed 20 January 2021. http://www.ancestrylibraryedition.co.uk.

"London, England, Church of England Baptisms, Marriages and Burials, 1558-1812".

Accessed 20 January 2021. http://www.ancestrylibraryedition.co.uk.

- . "London, England, Clandestine Marriage and Baptism Registers, 1667-1754". Accessed 20 January 2021. http://www.ancestrylibraryedition.co.uk.

—. "Westminster, London, England, Church of England Baptisms, Marriages and Burials, 1558-1812”. Accessed 20 January 2021. http://www.ancestrylibraryedition. co.uk.

Répertoire International des Sources Musicales (RISM). "RISM Catalog”. Accessed 20 January 2021. http://opac.rism.info.

\section{Eighteenth-Century Musical Sources}

Avison, Charles. Two Concertos, The First for an Organ or Harpsichord, in Eight Parts.

The Second for Violins, in Seven Parts. Newcastle: Joseph Barber, 1742.

Burgess, Henry, Jr. A Collection of English Songs and Cantatas. London: John Walsh, [1749].

- A Collection of Lessons for the Harpsichord Composed in an Easy and Familiar Style. London: John Johnson, [c. 1755].

- Six Concertos for the Harpsicord or Organ. London: author, [1743].

- Six Concertos for the Organ and Harpsichord, also for Violins \& Other Instruments in 5 Parts. London: Walsh, [1743 or later].

- Six Sonatas, for Two Violins and a Viloncello [sic], with the Thorough-Bass for the Harpsichord. London: author, 1781.

Burgess, Henry, Sr. A Collection of Lessons for the Harpsichord Composed in an Easy and Familiar Style. London: John Johnson, [c. 1755].

Calliope or English Harmony. Vol. 2. London: John Simpson, [1746].

Geminiani, Francesco. Concerti grossi con due violini, viola e violoncello di concertino obligati e due altri violini e basso di concerto grosso [...] composti delli sei soli della prima parte dell'Opera Quinta d'Arcangelo Corelli. London: William Smith, [1726]. Handel, George Frideric. "Psalmus 112” Dixit Dominus, HWV 232. London, The British Library (GB-Lbl), R.M.20.f.1.

_. "Suite Cinquieme" in E major, HWV 430. In Suites de pièces pour le clavecin, vol. 1. London: author, [1720].

- Six Concertos for the Harpsicord or Organ. London: John Walsh, [1738].

Hellendaal, Pieter. Six Grand Concerto's for Violins \&c. in Eight Parts, Op. 3. London: John Walsh, [1758].

The Musical Miscellany. Edited by John Watts. 6 vols. London: Watts, 1729-1731.

Vivaldi, Antonio. "Concerto" for Two Flutes, Two Oboes, Bassoon, Strings and Continuo, RV 566. Turin, Biblioteca nazionale universitaria (I-Tn), Foà 32, ff. 51-66. 
- "Concerto Con 2 Corni da Caccia", RV 538. Turin, Biblioteca nazionale universitaria (I-Tn), Giordano 31, ff. 164-175.

Modern Editions of Music

Burgess, Henry, Jr. Concerto V for Harpsichord or Organ. Edited by Francis Hopper. St Louis, MO: Concordia, [1968].

English Keyboard Concertos, 1740-1815. Edited by Peter Lynan. Musica Britannica 94. London: Stainer and Bell, 2013.

\section{Literature}

Bukofzer, Manfred F. Music in the Baroque Era from Monteverdi to Bach. London: Dent, 1948.

Burney, Charles. A General History of Music from the Earliest Ages to the Present Period. 4 vols. London: author, 1776-1789.

Burrows, Donald. Handel. Oxford: Oxford University Press, 1994.

Burrows, Donald, Helen Coffey, John Greenacombe and Anthony Hicks, eds. George Frideric Handel: Collected Documents. Vol. 1. Cambridge: Cambridge University Press, 2013.

Caldwell, John. English Keyboard Music Before the Nineteenth Century. New York: Dover, 1973.

Daub, Penny Ellen. "Music at the Court of George II (r. 1727-1760)". PhD diss., Cornell University, 1985.

Dawe, Donovan. Organists of the City of London 1666-1850. Padstow: author, 1983.

Drummond, Pippa. "The Royal Society of Musicians in the Eighteenth Century". Music \& Letters 59, no. 3 (1978): 268-289. https://doi.org/10.1093/ml/59.3.268.

Edwards, Owain Tudor. English Eighteenth-Century Concertos: An Inventory and Thematic Catalogue. Hillsdale, NY: Pendragon, 2004.

Fleming, Simon. "The Gender of Subscribers to Eighteenth-Century Music Publications". Royal Musical Association Research Chronicle 50 (2019): 94-152. https://doi.org/10.1080/14723808.2019.1570752.

Foster, Joseph. The Register of Admissions to Gray's Inn, 1521-1889, together with the Register of Marriages in Gray's Inn Chapel, 1695-1754. London: The Hansard Publishing Union, 1889.

Gudger, William D. "Handel and the Organ Concerto: What We Know 250 Years Later". In Handel Tercentenary Collection, edited by Stanley Sadie and Anthony Hicks, 271-278. Ann Arbor: UMI Research Press, 1987. https://doi.org/10.1007/978-1-349-09139-3_15. Hawkins, Sir John. A General History of the Science and Practice of Music. 5 vols. London: Payne, 1776.

Heighes, Simon. The Lives and Works of William and Philip Hayes. New York: Garland Publishing, 1995. https://doi.org/10.4324/9781315050942.

Highfill, Philip H., Kalman A. Burnim and Edward A. Langhans. A Biographical Dictionary of Actors, Actresses, Musicians, Dancers, Managers \& Other Stage Personnel in London, 1660-1800. 16 vols. Carbondale: Southern Illinois University Press, 1973-1993. 
Hunt, Rev. William H. The Registers of St. Paul's Church, Covent Garden, London. 5 vols. London: The Harleian Society, 1906-1909.

Johnstone, H. Diack. "The English Beat". In Aspects of Keyboard Music: Essays in Honour of Susi Jeans, edited by Robert Judd, 34-44. Oxford: Positif, 1992.

Johnstone, H. Diack, and Rosamond McGuinness. "Concert Life in England I". In The Blackwell History of Music in Britain, vol. 4, Music in Britain: The Eighteenth Century, edited by H. Diack Johnstone and Roger Fiske, 31-95. Oxford: Basil Blackwell, 1990.

Klima, Slava, Garry Bowers and Kerry S. Grant. Memoirs of Dr. Charles Burney, 1726-1769. Lincoln: University of Nebraska Press, 1988.

Lynan, Peter. "The English Keyboard Concerto in the Eighteenth Century". 2 vols. $\mathrm{PhD}$ diss., University of Oxford, 1997.

. "The Organ Concerto: Some Considerations of Evolution and Content". In Studies in English Organ Music, edited by Iain Quinn, 162-180. Boca Raton, FL: Routledge, 2018.

Matthews, Betty. The Royal Society of Musicians of Great Britain: List of Members, 1738-1984. London: Royal Society of Musicians, 1985.

Mortimer, [Thomas]. The Universal Director; or the Nobleman and Gentleman's True Guide to the Masters and Professors of the Liberal and Polite Arts and Sciences and of the Mechanic Arts, Manufactures, and Trades, Established in London and Westminster, and their Environs. London: Coote, 1763.

Rees, Abraham. The Cyclopaedia or Universal Dictionary of Art, Sciences and Literature. 39 vols. London: Longman, Hurst and Rees, 1819-1820. https://doi.org/10.5962/bhl. title.59683.

Rice, Paul F. The Solo Cantata in Eighteenth-Century Britain: A Thematic Catalog. Warren, MI: Harmonie Park Press, 2003.

Selfridge-Field, Eleanor. Venetian Instrumental Music from Gabrieli to Vivaldi. 3rd, rev. ed. New York: Dover, 1994.

Talbot, Michael. “From 'Sonate a quattro' to 'Concertos in Seven Parts': The Acclimatization of Two Compositions by Francesco Scarlatti”. In Musicians' Mobilities and Music Migrations in Early Modern Europe: Biographical Patterns and Cultural Exchanges, edited by Gesa zur Nieden and Berthold Over, 311-321. Bielefeld: transcript, 2016. https://doi.org/10.14361/9783839435045-017.

. "William Bates and His Concertos in Ten Parts, Op. 2: An Enterprising Eighteenth-Century Composer and an Unrecognized Orchestral Subgenre Employing Horns". Eighteenth-Century Music 14, no. 2 (2017): 235-263. https://doi.org/10.1017/S1478570617000069.

- Vivaldi and Fugue. Florence: Olschki, 2009.

Van Lennep, William, Emmet Langdon Avery, Arthur H. Scouten, George Winchester Stone and Charles Beecher Hogan. The London Stage, 1660-1800. 5 vols. Carbondale, IL: Southern Illinois University Press, 1965-1968.

Wroth, Warwick. The London Pleasure Gardens of the Eighteenth Century. London: Macmillan, 1896. 


\section{ORGELSKI KONCERTI HENRYJA BURGESSA (1718-1786)}

\section{Povzetek}

Henry Burgess je bil med prvimi v Angliji rojenimi ustvarjalci in izvajalci izrazito angleške vrste koncerta - tj. orgelskega koncerta (ki se je lahko izvajal tudi solo na čembalu) - nastale po vzoru šestih primerov, ki jih je leta 1738 objavil Händel kot op. 4. Angleški skladatelji so podobne koncerte v velikem številu ustvarjali vse do konca stoletja. Burgessov niz šestih koncertov je izšel leta 1743 in je vključeval dela, ki jih je Burgess ob orkestrski spremljavi od leta 1739 izvajal v Londonu, večinoma v gledališču Drury Lane. Burgess jih je izdajal zasebno po naročilu, njegov glavni zastopnik pa je bil John Walsh. Čez kako leto (kar je bila običajna praksa med londonskimi skladatelji) je tiskarske plošče predal Walshu, ki se je od takrat naprej predstavljal kot založnik .

Burgess se je rodil v glasbeni družini v župniji Saint-Martin-in-the-Fields v Londonu. Njegov oče, ki je imel enako ime, se je rodil v 60. letih 17. stoletja in umrl leta 1765. Henry Burgess starejši je od leta 1723 do svoje smrti igral instrumente s tipkami v Royal Band of Musicians. Pisal je tudi svoje skladbe in sredi 50. let 18. stoletja izdal zbirko suit za instrumente s tipkami. Henry Burgess mlajši, po domače »Harry«, si je kot glasbenik na instrumentih s tipkami ime najverjetneje ustvaril že v najstniških letih, in čeprav za to ni pisnih dokazov, naj bi v času, ko je začel izvajati svoje koncerte v gledališču Drury Lane, že bil hišni čembalist v tem gledališču. O tem, da bi tam nastopal tudi po letu 1745, ni podatkov, in zdi se, da je bil od takrat njegov glavni vir dohodka poučevanje glasbe. Še naprej je skladal: leta 1749 je Walsh izdal zbirko njegovih pesmi in kantat, leta 1781 pa je zasebno izdal niz devetih trio sonat za dve violini, čelo in basso continuo. Umrl je leta 1786.

Burgessovi koncerti so ob izdaji povzročili precejšnje razburjenje in zdi se, da so močno vplivali na razvoj prve generacije orgelskih koncertov v Angliji, zlasti skladateljev, kot sta William Hayes in William Felton. Zgodovinar, skladatelj in organist Charles Burney je Burgessa hvalil kot izvajalca in skladatelja, čeprav z nekaterimi zadržki, ki odražajo njegovo poznejšo naklonjenost bolj »modernemu« (tj. posthändelskemu) slogu. Slava, ki so si jo Burgessovi koncerti prislužili, pa je kmalu zbledela in do danes se o njih in njihovem skladatelju ni več kaj dosti slišalo.

Ta zapostavljenost je neupravičena, saj so njegovi koncerti privlačna in zelo spretno napisana dela, ki kažejo veliko mero izvirnosti. S slogovnega vidika združujejo prvine Vivaldijevih in Händlovih del, hkrati pa vključujejo tudi značilnosti, ki izhajajo iz angleške plesne in pesemske tradicije. Zaključni hitri stavki v binarni obliki imajo ločene uvode brez ponovitve, ki so očitno sposojeni iz vokalne glasbe. Večina glasbe za solista vključuje neprekinjene pasaže v motoričnem ritmu, občudovanja vreden pa je način, kako se skozi pasaže razvijata figuracija in tekstura.

Kot je bilo značilno za obdobje, v katerem so nastali, so Burgessovi koncerti primerni za različne kontekste, ne samo za javne koncerte in nastope v gledališčih, ampak tudi za ljubiteljsko igranje in domače muziciranje. Izvajajo se lahko bodisi s spremljavo violin, viole, čela in bassa continua bodisi solistično na instrumentu s tipkami. Orkester se lahko opusti, ker so solistični deli vedno brez spremljave, »tutti« in »senza organo« deli pa se lahko vedno, vsaj okvirno, izvedejo na instrumentu s tipkami, ki igra od začetka do konca. 